Fernando da Silva Pereira

\title{
POLÍTICA INDUSTRIAL NA REESTRUTURAÇÃO PRODUTIVA DA CADEIA AUTOMOTIVA NACIONAL: DA ABERTURA ECONÔMICA ATÉ O PERIIODO RECENTE
}

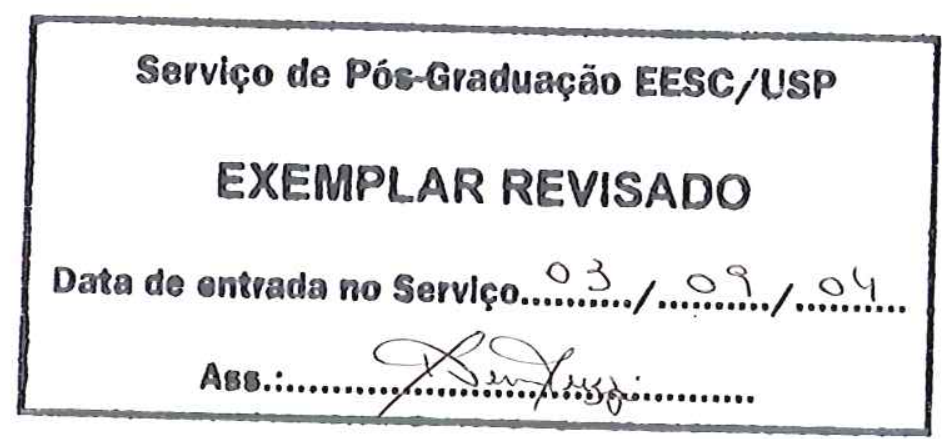

Dissertação apresentada à Escola de Engenharia de São Carlos, da Universidade de São Paulo, como parte dos requisitos para o Título de Mestre em Engenharia de Produção.
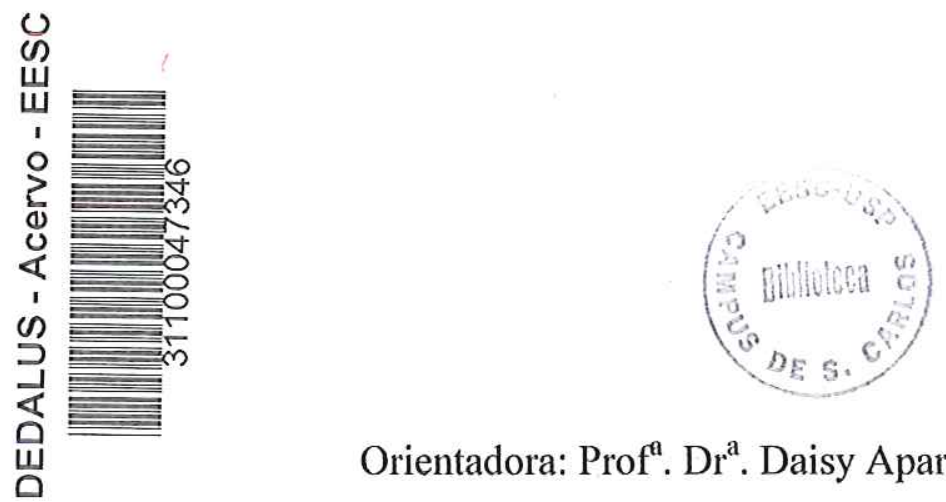

Orientadora: Prof ${ }^{\mathrm{a}}$. Dr ${ }^{\mathrm{a}}$. Daisy Aparecida do Nascimento Rebelatto 
Candidato: FERNANDO DA SILVA PEREIRA

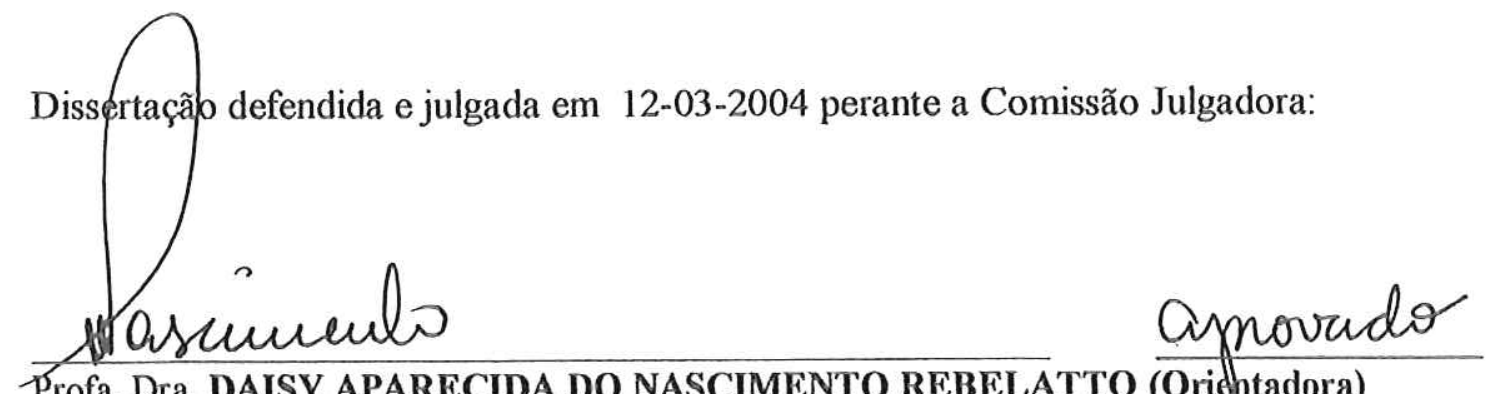
Profa. Dra. DAISY APARECIDA DO NASCIMENTO REBELATTO (Oridhtadora) (Escola de Engenharia de São Carlos/USP)

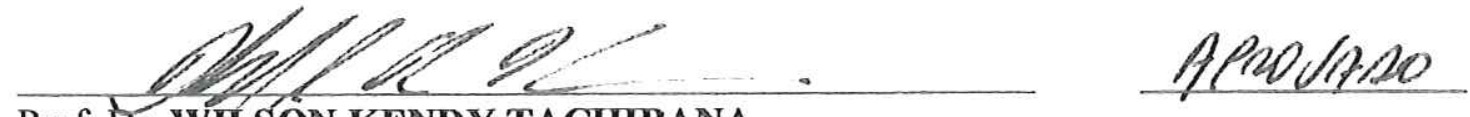

Prof. Dr. WIILSON KENDY TACHIBANA

(Escola de Engenharia de São Carlos/USP)
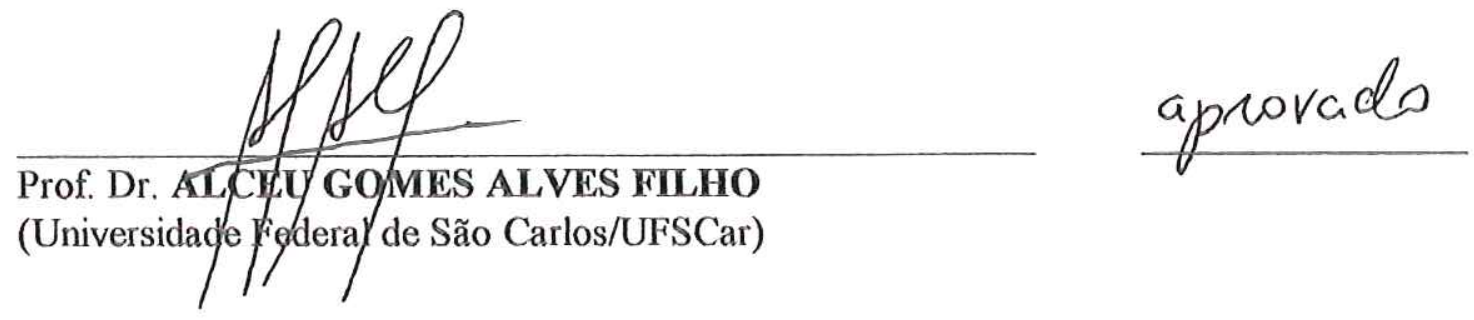

(Universidage figdera) de São Carlos/UFSCar)

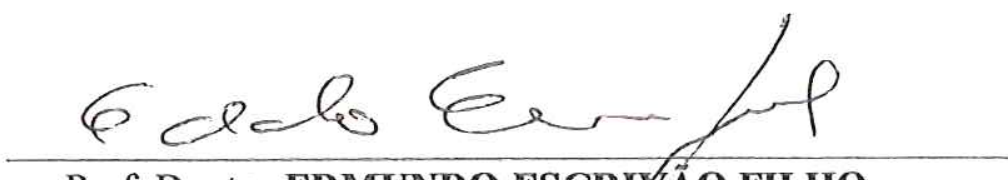

Prof. Doutor EDMUNDO ESCRYYÄO FIL.HO

Coordenador do Programa de Pós-Graduação em Engenharia de Produção

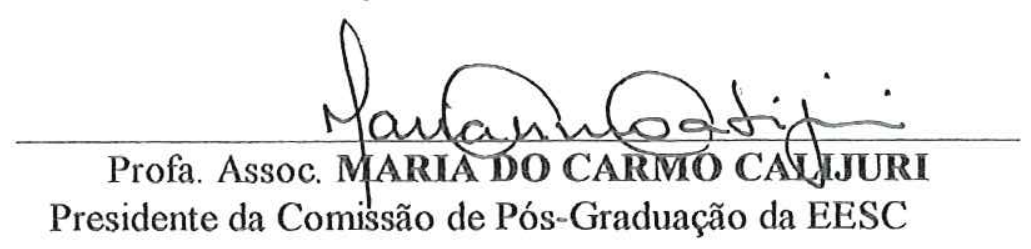


Dedico este trabalho aos meus pais, Helena da Silva Pereira e João Batista Pereira exemplos de luta e perseverança - fundamentais em todas as minhas conquistas e em minha vida. 


\section{AGRADECIMENTOS}

Este trabalho corresponde ao resultado final da etapa mais árdua e conturbada da minha vida. Uma etapa na qual foram vários os momentos de lutas e vitórias, mas também estiveram presentes momentos de tristeza e desapontamento. Mesmo tendo a consciência de que essas linhas não serão suficientes, devido ao valioso papel dessas pessoas ao longo do período do meu mestrado, quero aqui registrar os meus sinceros agradecimentos àqueles que tornaram possível essa conquista.

Em primeiro lugar quero agradecer à minha orientadora, a Profa. Dra. Daisy Aparecida do Nascimento Rebelatto. Ao longo do mestrado, acima de uma orientadora, ela se mostrou como uma grande amiga e incentivadora. Devo a ela o fato de ter conseguido chegar até aqui, pois foi a profa. Daisy que primeiramente confiou no meu trabalho e no meu potencial. Ela soube compreender o contexto difícil que passei ao longo desses últimos anos, foi além de seu papel como orientadora ao criar meios para que eu conseguisse superar minhas fraquezas. Foi ela quem abriu as primeiras portas para o meu desenvolvimento profissional e com grande tolerância e atenção sempre esteve ao meu lado, mesmo nos momentos em que me mostrei distante e acho que até mesmo não merecedor de tão grande apoio.

Agradeço ao Prof. Dr. Wilson Kendy Tachibana, que além de ter composto tanto a banca da qualificação quanto a banca da defesa, foi um dos professores que mais colaboraram com a minha formação, ao destacar idéias e argumentos que serviram de inspiração e me fizeram pensar e evoluir na minha área profissional. Serei sempre grato ao professor Tachibana, por todo o apoio dispensado durante esses últimos anos. De suas aulas obtive o meu primeiro artigo publicado e uma das melhores participações em seminários que já realizei.

Agradeço ao Prof. Alceu Gomes Alves Filho, que compôs as bancas de qualificação e de defesa. Sua colaboração foi crucial para desenvolvimento e o encerramento dessa pesquisa. Seus comentários, extremamente pertinentes, foram valiosos ensinamentos que me fizeram repensar e aprimorar a argumentação presente nessa pesquisa e serão de grande importância para o meu desenvolvimento futuro como pesquisador.

Devo aqui agradecer também ao Prof. Edmundo Escrivão Filho, pois a qualidade incontestável de suas duas disciplinas complementou em muito a minha formação profissional. Além disso, o prof. Edmundo se mostrou como um exemplo a ser seguido nessa profissão de professor/pesquisador/pensador.

Não posso deixar de citar os funcionários que me apoiaram no Departamento de Engenharia de Produção da USP de São Carlos, em particular o José Luiz Donizete Chiaretto, a Silvana Ap. Araújo Celestini e o Luiz Fernando Ferreira. Vocês sempre se colocaram a minha disposição nos momentos em que necessitei - sou e serei sempre grato por toda a atenção que vocês me dispensaram ao longo desse período. 
Agradeço também aos amigos que tornaram essa jornada um pouco mais leve e me deram forças no momento em que as minhas já me faltavam. No que se refere à torcida, devo destacar os eternos companheiros de república e de faculdade André Franco, Alex da Ros, Adriano Cambuí, Cristiane Feltre, Giana Chierice, Jarbas, Mauro (Pajé), Paulo Camuri, Ricardo Casetta e Rogério Nohara.

Agradeço em especial a Jorge Meirelles, grande amigo e companheiro de trabalho, que por ter convivido comigo na faculdade e ao longo do mestrado foi uma das pessoas que mais estiveram presentes e me apoiaram nessa jornada.

Ao Daniel Jugend e ao Willy Gentil de Goes também faço um agradecimento especial pois foram eles que conviveram comigo com mais intensidade nos momentos finais do meu trabalho. Eles me apoiaram no momento mais difícil e também foram os alvos principais do meu mau humor.

Devo também destacar uma pessoa que consiste numa presença muito forte na minha vida, Carolina Almeida Araújo de Andrade. Devo a ela a motivação que me levou a trilhar esse caminho acadêmico e sou grato, hoje e sempre, por todo o carinho e amizade que me foi e é dispensado.

Agradeço também à Thais Pereira, ao José Roberto Ribeiro, ao Rodrigo Vidotto, à Luciana Pereira, à Adriana Kazue Takeuchi, ao Leonardo Pradella, ao Sidnei, ao Marcelo Nadai, ao Cristiano Silva, à Michele Nadai, à Mônica Sepúlveda, à Patrícia Zambel, à Lúcia Okuda, à Noêmia Fuji, ao Eric, ao Luís Carlos Costa, à Luciara Feltrin e a todos os demais amigos que direta ou indiretamente estiveram presentes na minha vida e sempre torceram pelo meu sucesso.

Para encerrar, devo destacar aqueles que merecem o meu maior agradecimento, meus pais, Helena e João. Essa conquista também pertence a vocês, pois vocês sempre estiveram e estarão ao meu lado. 
"O pessimista se queixa do vento. O otimista espera que ele mude. O realista ajusta as velas."

Willian George Ward, teólogo inglês (1812 - 1882). 
RESUMO

PEREIRA, F. S. (2004). Política industrial na reestruturação produtiva da cadeia automotiva nacional: da abertura econômica até o período recente. Dissertação (Mestrado) - Escola de Engenharia de São Carlos, Universidade de São Paulo, São Paulo, São Carlos, 2004.

O processo de abertura da economia brasileira, intensificado nos anos 90, e a relativa estabilidade monetária conquistada com o Plano Real (1994), propiciaram reestruturações em grande parte do tecido industrial brasileiro e, conseqüentemente, em seus padrões de produtividade e competitividade. A cadeia automotiva instalada no Brasil é uma referência neste contexto. Este trabalho tem como objetivo analisar os efeitos da política industrial implementada pelo Estado sobre o processo de reestruturação produtiva da cadeia automotiva nacional, a partir do conhecimento disponível sobre esse processo, ocorrido durante o período que se inicia nos anos 90 (com a intensificação da abertura econômica) e segue até o final do ano de 2003. O presente trabalho analisa quais foram os instrumentos de política industrial utilizados pelo Estado ao longo do período e se tais instrumentos geraram ganhos ou perdas no que se refere ao aumento da eficiência e eficácia econômica e produtiva na cadeia automotiva nacional.

Palavras-chave: política industrial, reestruturação produtiva, cadeia automotiva, indústria automobilística brasileira. 
ABSTRACT

PEREIRA, F. S. (2004). Industrial Policy in a New Productive Framing in Brazilian Automotive Chain: from the Beginning of the Economy Opening Process until Nowadays. M.Sc. Dissertation - Escola de Engenharia de São Carlos, Universidade de São Paulo, São Paulo, São Carlos, 2004.

The opening process of brazilian economy, intensified in 1990's, and the monetary stability achieved with the Plano Real (1994), originated a new framing in a large part of brazilian industrial body and, consequently in their pattern of productivity and competitive ways. The automotive chain installed in Brazil is a reference in this context. This work deals with the analysis of the effects of Industrial Policy put in practice by the State in the process of creation of a new framing in the brazilian automotive chain, using the knowledge available about this process, occurred from the beginning of 90's until the last days of 2003. This work analysis the tools of industrial policy used by the brazilian government throughout this period and if these tools generated gain or damage about the increase of economic and productive efficiency and efficacy of the automotive chain in Brazil.

Keywords: Industrial Policy, New Framing Production, Automotive Chain, Brazilian Automotive Industry. 

A. A FormulaÇão do Problema
B. OBJetivo 10
C. Delineamento da Pesquisa 11
D. O Procedimento MetodolóGico 13
E. A Estrutura do Trabalho 16

PARTE I - ELEMENTOS PARA A DISCUSSÃO 17

CAPÍTULO I - EMPRESA, CADEIA PRODUTIVA, MERCADO E REESTRUTURACÃO

$\begin{array}{lr}\text { 1.1. EMPRESA } & 19\end{array}$

\begin{tabular}{ll} 
1.2. & Cadeia Produtiva \\
\hline
\end{tabular}

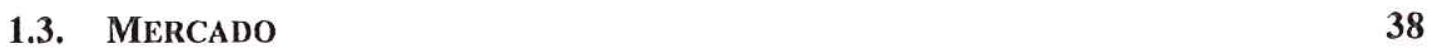

1.4. REESTRUTURAÇ̃̃o PRODUTIVA 41

CAPÍTULO II - POLÍTICA INDUSTRIAL $\quad 42$

2.1. POLÍtica INDUSTRIAL: DEFINIÇÃo 42

2.2. PRINCIPAIS VISÕES

2.2.1 Política INDUSTRIAL E FALHa DE MERCAdo 5

2.2.2 POLÍtica INDUSTRIAL E DESENVOLVIMENTO

$\begin{array}{lll}\text { 2.2.3 } & \text { POLÍtica INDUSTRIAL E INOVAÇão } & 58\end{array}$

2.3. InStrumentos De Política Industrial $\quad \mathbf{6 0}$ 
3.2. EVOLUÇão DA CADEIA AUTOMOTIVA AO LONGO DO PERÍODO ESTUDADO

CAPÍTULO IV - POLÍTICA INDUSTRIAL NA REESTRUTURAC̄̃̃O PRODUTIVA

4.1. A POlítica industrial: DA ABERTURA ECONÔMICA AO SURGIMENTO DAS CÂMARAS SETORIAIS 87

4.1.1. A ATUAÇão Das CÂMARAS SETORIAIS 90

4.2.2. 1994: NOVOS RUMOS PARA A POLÍTICA INDUSTRIAL 91

4.2.3 Os inVestimentos na Cadeia Automotiva 91

4.2.4 CRISES ECONÔMICAS E COMPETIÇÃO EM MERCADO ESTAGNADO 92

4.3. 2003: O PRIMEIRO ANO DE UM NOVO GOVERNO 94 


\section{APRESENTAÇÃO}

O processo de abertura da economia brasileira, intensificado nos anos 90 , e a relativa estabilidade monetária conquistada com o Plano Real (1994) propiciaram reestruturações em grande parte do tecido industrial brasileiro e, conseqüentemente, em seus padrões de produtividade e competitividade.

A cadeia automotiva instalada no Brasil, composta por montadoras, seus diversos fornecedores, consumidores e todos os trabalhadores, além das demais instituições envolvidas, é uma referência quando se discutem as diversas mudanças ocorridas no universo composto pelas empresas locais a partir do início dos anos 90 .

Com a abertura econômica ocorrida no Brasil, ficou evidente a defasagem de grande parte da estrutura produtiva do país se comparada às estruturas industriais dos países desenvolvidos, as quais, ao longo das décadas anteriores, haviam passado por um vasto processo de reestruturação produtiva que até aquele momento não havia se difundido de forma ampla entre empresas brasileiras.

No que se refere às montadoras de automóveis, foi possível uma nova inserção das filiais aqui instaladas nas estratégias formuladas pelas matrizes em âmbito global e, portanto, na competição global. Além disso, outro ponto que não deve ser desprezado é a entrada de novos competidores ocorrida a partir de então, que trouxe consigo o acirramento da disputa pelo mercado interno e o fim de uma situação de estagnação e protecionismo que havia consolidado um mercado dominado e dividido entre quatro das grandes montadoras globais (Fiat/Itália, General Motors/EUA, Volkswagen/Alemanha e Ford/EUA).

Esse novo cenário redefiniu as possibilidades, necessidades e pretensões dos agentes relacionados à cadeia automotiva brasileira. A partir de investimentos, da 
implantação de novas plantas produtivas, de fusões e aquisições e principalmente do estabelecimento de novas relações entre os diversos agentes envolvidos, a organização industrial até então vigente alterou-se até atingir seu estágio atual, um estágio talvez inimaginável nos primórdios dos anos 90 .

Este trabalho discute como a ação do Estado, a partir dos instrumentos de política industrial, afetou o processo de reestruturação produtiva que se desenrolou na cadeia automotiva brasileira a partir dos anos 90 . Um processo de reestruturação amplo e ainda em marcha.

\section{A. A Formulação do Problema}

A cadeia automotiva instalada no Brasil apresenta-se como uma das principais atividades produtivas afetadas pela grande reestruturação ocorrida no tecido industrial nacional a partir da intensificação do processo de abertura de nossa economia. Segundo ARBIX \& ZILBOVICIUS (1997), é a partir das mudanças implementadas no início dos anos 90 que a cadeia automotiva irá realizar uma grande inflexão em sua trajetória:

"No Brasil dos anos 90, as corporações transnacionais do setor automobilístico, levadas a produzir em um novo ambiente econômico, estão realizando uma profunda inflexão em sua trajetória, (re)estruturando-se, (re)investindo ou implantando novas fábricas de um modo só comparável à primeira grande entrada no país quando do nascimento da indústria na década de 1950" (ARBIX \& ZILBOVICIUS, 1997, p.449).

Tal situação encontra explicações que vão além do contexto nacional. Diversos fatores ocorridos em âmbito internacional somam-se aos elementos 
explicativos locais, os quais, agindo em conjunto, proporcionaram uma dinâmica competitiva singular para a indústria automobilística brasileira.

No espaço internacional, houve grandes mudanças de caráter tecnológico e institucional que provocaram a aceleração do processo de internacionalização das diversas economias nacionais. A globalização produtiva, entendida aqui como a produção e a distribuição de valores dentro de redes em escala mundial e o acirramento da concorrência entre grandes grupos multinacionais, passa a assumir um papel de destaque, devido às possibilidades de progresso tecnológico, ganhos de eficiência, e ganhos mercantis a ela associados (VASCONCELLOS et al. 1999, p.340). A partir dos anos 80, o processo de globalização produtiva intensificou-se sobre a cadeia automotiva internacional, a qual pode ser vista como um dos principais exemplos relacionados a este processo.

Houve o acirramento da competição entre as grandes montadoras, a intensificação do desenvolvimento e da difusão de novas tecnologias em diversas áreas da produção, comercialização e distribuição. As montadoras japonesas, e de forma pioneira a Toyota, que haviam modificado a lógica produtiva vigente até aquele momento, a partir de uma nova forma de organização da produção, distinta daquela empregada como modelo de eficiência e eficácia no Ocidente (o fordismo/taylorismo), obtiveram ganhos surpreendentes de produção e de mercado internacional.

No que se refere à cadeia automotiva brasileira, e de modo particular às montadoras, se, no final dos anos 80 , apresentavam-se estagnadas e muito aquém dos padrões de qualidade e produtividade de suas similares no exterior, devido principalmente ao protecionismo existente em nosso país e ao desinteresse das 
próprias matrizes, mais preocupadas com a competição nos mercados americanos e europeus naquele momento, conforme destaca HOLLANDA FILHO (1996), com a abertura econômica estas organizações se inserem novamente nas estratégias competitivas de suas matrizes e conseqüentemente no processo de globalização produtiva.

É com a abertura econômica que o Brasil encerra um período caracterizado por políticas de substituição de importações e foco no mercado interno, no qual o mercado externo era visto como secundário pelas empresas instaladas no país (GREMAUD et. al., 2004) e se inicia um novo momento em que o tema globalização, em particular no seu aspecto produtivo, devido à grande presença de firmas transnacionais ${ }^{1}$, passa a se destacar nas discussões sobre o progresso da industria nacional e também passa a ser um tema a ser considerado na tomada de decisões dos agentes aqui situados, em especial as decisões do Estado, ligadas à política industrial.

Devido a esse novo contexto nacional e internacional, a cadeia automotiva brasileira passou a enfrentar diversos desafios que acabaram the impondo um processo de reestruturação produtiva singular, tanto se comparado à sua trajetória até então quanto se visto em relação ao processo em andamento na cadeia automotiva internacional. Esta realidade culminou em uma situação muito distinta daquela vivida antes da abertura econômica, como observado por VILADARGA, já no ano 2000:

"Foi-se o tempo em que a indústria automobilística olhava de lado para o Brasil. Se os projetos do setor eram vagarosos e tímidos ao longo dos anos 70 e 80,

\footnotetext{
${ }^{1}$ Por exemplo, o setor montador de veículos automotores é dominado por empresas transnacionais no Brasil, as empresas de capital nacional apresentam-se de forma marginal, atuando apenas em nichos de mercado.
} 
quando apenas quatro grandes marcas produziam carros no país, hoje eles só sugerem ambição. De mercado sem opções, preços altos e sem crédito, conhecido pelos produtos antiquados, o Brasil virou um fenômeno automobilístico mundial" (GAZETA MERCANTIL, 04/08/2000, p. C1). Este trecho destaca as expectativas com relação à cadeia automotiva vividas em um momento recente (neste caso, em meados de 2000), porém, desde a abertura econômica a cadeia automotiva brasileira passou por diversos momentos de euforia e desapontamento no que diz respeito às possibilidades previstas para o mercado interno e para a inserção da cadeia automotiva aqui instalada no mercado internacional.

Tendo partido de um ambiente negativo, em que as atitudes reativas eram a característica marcante, dada a grave situação de crise vivida ao longo dos anos 80 , a cadeia automotiva brasileira, já a partir de 1994, torna-se um espaço propício a atitudes pró-ativas por parte das montadoras, tanto em relação aos seus competidores (estabelecidos ou potenciais), quanto em relação à inserção de inovações tecnológicas (quer sejam de produto e/ou de processo) e à realização de novos investimentos. A competição se intensificou na cadeia automotiva brasileira e se destacou como uma das maiores preocupações entre as grandes montadoras desde então, quer sejam as já estabelecidas ou as entrantes (newcomers).

Tais elementos proporcionaram uma situação completamente distinta daquela apresentada por ARBIX (1996) referente ao início dos anos 90, na qual grande parte das montadoras mostrava sinais de desinvestimento e até mesmo de encerramento de atividades.

Neste contexto, é de grande relevância como elemento explicativo o papel do Estado sobre as condutas dos agentes que compõem a cadeia automotiva nacional. A 
partir de diversos instrumentos ligados à política industrial - quer sejam direcionados ao setor ou de caráter mais amplo - o Estado agiu sobre o processo de reestruturação produtiva que se desenrolou ao longo deste período, tendo afetado com isso o desempenho e a relação existente entre os agentes envolvidos.

As montadoras são as organizações que devido à suas competências interagem com todos os agentes que compõem a cadeia. Qualquer mudança relevante gerada por elas impacta a cadeia automotiva como um todo e mudanças geradas pelos demais agentes envolvidos, como o Estado e os grande fornecedores, impactam estas organizações.

Com a abertura econômica, o Estado brasileiro, na figura dos governos federais que se sucederam, foi obrigado a tomar medidas relacionadas ao tema política industrial distintas daquelas empregadas anteriormente. Essas medidas deveriam visar a reestruturação de setores pouco competitivos internacionalmente (em especial a cadeia automotiva nesse trabalho) e possibilitar ganhos de competitividade e produtividade capazes de promover o desenvolvimento econômico.

É digno de nota que certos avanços foram obtidos, porém, a ação do Estado, no que se refere à política industrial adotada, merece atenção particular. Isso é importante para que seja possível compreender e ponderar o real papel desta ação sobre o processo de reestruturação produtiva desenvolvido na cadeia automotiva brasileira, já que sua evolução apresentou variações de condutas ao longo do tempo.

Desta forma, convém destacar algumas questões relevantes que surgem a partir destas observações. Em primeiro lugar, quais foram os instrumentos de política industrial adotados no processo de reestruturação produtiva ocorrido 
na cadeia automotiva brasileira? Como a política industrial se caracterizou a partir do período que se inicia com a abertura econômica do início dos anos 90 ? Houve mudanças significativas no que se refere às ações ligadas à política industrial devidas às mudanças ocorridas no governo federal ao longo do período? Além destes pontos, que tipo de resultados podem ser atribuídos à política industrial adotada ao longo do período?

Atualmente, ao observar a cadeia automotiva nacional, é possível notar que a competição entre as montadoras apresenta-se como um dos elementos de maior destaque no estágio atual do seu processo de reestruturação produtiva. Isso vem ocorrendo em um contexto no qual a demanda encontra-se reprimida e aquém daquilo que havia sido previsto quando os principais investimentos foram realizados, a partir de meados dos anos 90, mas no qual há também uma grande expectativa de reaquecimento da demanda para o futuro próximo e o aparente surgimento de novas oportunidades no mercado internacional.

Hoje, as principais montadoras mundiais possuem atividades produtivas no país e disputam com maior intensidade posições no mercado. Este contexto torna a realidade atual bem distinta daquela observada no início dos anos 90 e implica na perda de participação no mercado nacional de algumas montadoras estabelecidas antes da abertura econômica e no surgimento de estratégias competitivas distintas entre os participantes, as quais, visam obter o maior retorno possível das possibilidades presentes no ambiente econômico nacional, vindas das relações destas empresas com os demais agentes envolvidos, sendo que atenção especial é dada por essa dissertação sobre as relações entre montadoras e Estado, devido ao grande poder de influência mútua existente entre esses agentes. Este ponto é relevante e deve ser 
analisado com cuidado, para responder como foram e se existem disparidades nas relações e também se tais disparidades (caso existam) são exploradas pelos agentes econômicos, tendo atenção particular nas montadoras e no Estado, durante o período estudado.

As observações aqui apresentadas são pertinentes devido ao papel que assume a cadeia automotiva brasileira na produção industrial nacional, como vetor de inovações, como grande empregador e como grande participante da balança comercial brasileira. Além disso, a partir da discussão sobre as questões aqui destacadas, foi possível realizar um breve balanço sobre o tema desenvolvido neste trabalho, capaz de destacar diversas questões ligadas à cadeia automotiva nacional, que poderão ser úteis aos formadores de opinião, empresários ligados à cadeia, formuladores de políticas e outros interessados, no sentido de auxiliar no objetivo destes de compreender a cadeia automotiva brasileira e talvez tornar viável a superação de possíveis falhas ocorridas no passado e a conquista do desenvolvimento ligado a esta cadeia produtiva no futuro.

\section{B. Objetivo}

Este trabalho tem como objetivo discutir os efeitos da Política Industrial implementada pelo Estado sobre o processo de reestruturação produtiva da cadeia automotiva nacional, a partir do conhecimento disponível sobre esse processo, ocorrido durante o período que se inicia nos anos 90 (com a intensificação da abertura econômica) e segue até o final do ano de 2003.

O presente trabalho vai analisar quais foram os instrumentos de política industrial utilizados pelo Estado ao longo do período e quais as implicações geradas pelas ações do Estado sobre o desenvolvimento da cadeia automotiva nacional. 


\section{Delineamento da Pesquisa}

Neste ponto é conveniente destacar algumas das principais características deste trabalho, de maneira a evidenciar certas particularidades das observações que foram realizadas. Além disso, esse item também visa delimitar certos elementos que constituem o escopo do trabalho.

No que diz respeito às hipóteses deve ficar claro que as montadoras de veículos automotores e comerciais leves assumem um papel central na análise do processo de reestruturação produtiva na cadeia automotiva, devido às suas características como organizações produtivas, as quais serão destacadas ao longo do texto.

O Estado, a partir dos instrumentos de política industrial, afeta o processo de tomada de decisões econômicas dos agentes produtivos - influenciando-o, porém, o próprio Estado não é imune em suas decisões à influência dos demais agentes que compõem a cadeia automotiva nacional. Cabe destacar que a influência das montadoras de veículos automotores e comerciais leves sobre o governo, por exemplo, é vista com atenção particular.

No que se refere ao escopo da pesquisa, deve-se ter em mente que ao utilizar o termo cadeia automotiva brasileira o trabalho está se referindo especificamente à cadeia que possui como seu centro as montadoras de veículos automotores e comerciais leves, comumente chamados de automóveis ou carros.

A amplitude desta cadeia, no que se refere aos encadeamentos para trás das montadoras, envolve os fabricantes de autopeças que fornecem seus produtos às próprias montadoras, quer sejam na forma de sistemas ou de peças e componentes isolados, direta ou indiretamente. É composta, portanto, pelo que a literatura 
convencionou chamar de níveis de fornecedores ou fornecimento, em especial pelo primeiro, segundo e terceiro níveis de fornecimento.

Quanto aos encadeamentos para frente, são considerados como elementos constituintes da cadeia automotiva as revendedoras de automóveis novos e comerciais leves, juntamente com os consumidores de tais revendedoras.

Não são considerados como elementos constituintes da cadeia, neste trabalho, os fornecedores de bens primários, as fábricas e revendedoras de veículos comerciais pesados, como caminhões e ônibus de médio e grande porte, além dos fornecedores de aço e outros produtos metálicos. Também não fazem parte da cadeia analisada os fabricantes de máquinas e implementos agrícolas, o mercado de peças para reposição e o mercado de veículos usados. Tais exclusões justificam-se pela dinâmica distinta existente nos mercados atendidos por esses produtos e produtores e a relação particular destes com a cadeia automotiva nacional, em especial com as montadoras de automóveis.

Quanto ao corte temporal, o período escolhido se inicia com a abertura econômica nos anos 90. Isso se justifica porque as mudanças no âmbito de nossa cadeia automotiva intensificaram-se a partir do processo de abertura, como fica claro a partir da leitura da revisão bibliográfica realizada e do texto de HOLLANDA FILHO (1996), por exemplo. Este momento mostra-se como um "divisor de águas" para a cadeia automotiva nacional, conforme destaca esse autor, já que antes da abertura a dinâmica industrial era distinta daquela que veio a se desenvolver a partir dos anos 90. Além disso, a política industrial adotada apresentava outras características. Essas observações permitiram supor que o estado atual da cadeia automotiva nacional se explica, em certa proporção, pela forma como foi realizado 
este processo no início dos anos 90, um momento sempre evidenciado na bibliografia pertinente a esta cadeia produtiva, e que por esses motivos não poderia ser excluído desta análise.

As análises foram até o final de 2003, já que esse pode ser considerado como o primeiro ano de uma mudança no quadro político brasileiro. Além disso, o ano de 2003 apresenta características conjunturais interessantes e que serão de grande importância para a compreensão do "estado da arte" do tema aqui discutido.

Foi respeitada a cronologia dos acontecimentos, porém, tal cronologia foi discutida em períodos e não em anos específicos, salvo aqueles que eram de extrema relevância para o cumprimento dos objetivos aqui propostos.

\section{O Procedimento Metodológico}

Segundo BOTOMÉ (1997), o método de pesquisa não busca ser um meio que limita as possibilidades de ação do investigador, mas sim uma ferramenta que auxilia o pesquisador nas decisões e na orientação de uma conduta mais eficaz e econômica no processo de geração do conhecimento.

As perguntas principais que este trabalho buscou responder surgiram na etapa de formulação do problema de pesquisa e, após o Exame de Qualificação e diversas ponderações feitas pelo autor, se consolidaram dando origem ao objetivo geral explicitado neste texto. Conforme TRIVIÑOS (1987), as questões de pesquisa são o que, de fato, o pesquisador pretende esclarecer em sua pesquisa, e servem para orientar e nortear seu trabalho.

Com relação ao método de pesquisa propriamente dito, deve-se ter em mente que ele nada mais é do que o conjunto de instrumentos utilizados para se encontrar respostas para as questões propostas (SILVA \& MENEZES, 2001). 
A análise realizada foi um estudo descritivo. Segundo TRIVIÑOS (1987), o estudo descritivo tem como objetivo descrever de forma bastante exata, fatos e fenômenos de determinada realidade, e exigem do pesquisador uma série de informações sobre o tema que se pretende pesquisar. Para CERVO \& BERVIAN (1983) a pesquisa descritiva busca conhecer diversas situações e relações da vida humana, no nível social, econômico, político e nos demais aspectos do comportamento dos indivíduos e dos grupos sociais.

Para realizar o trabalho, as etapas desenvolvidas foram a revisão bibliográfica e a análise e apresentação dos resultados, ou seja, a pesquisa descritiva propriamente dita.

A primeira etapa desenvolvida foi a revisão bibliográfica, a qual foi de suma importância, já que o trabalho aqui apresentado deve ser visto como uma argumentação desenvolvida a partir do conhecimento produzido e explicitado nos diversos dados e textos que compõem a revisão.

No primeiro momento a revisão buscou identificar elementos conceituais e teóricos capazes de desenvolver a capacidade de inferência sobre o objeto a ser analisado na dissertação (a cadeia automotiva nacional). Tomou-se como referência elementos vindos da Economia e da Engenharia de Produção, devido a maior familiaridade do autor com essas áreas e a aderência destas à discussão aqui realizada.

Logo após esta primeira etapa, a revisão bibliográfica se ateve a informações que envolvem e conceituam itens referentes ao tema principal da dissertação - a política industrial na reestruturação produtiva da cadeia automotiva - e àqueles que o circundam. Para tanto, foram utilizados materiais bibliográficos e científicos, como 
dados de desempenho da cadeia ao longo do período, obtidos na Associação Nacional dos Fabricantes de Veículos Automotores (ANFAVEA) e outros órgãos, livros, dissertações, teses, artigos de revistas e jornais, veiculados em meio impresso ou eletrônico.

Para esta dissertação deve ficar claro que a revisão bibliográfica, além de ter sido uma etapa específica do trabalho, foi um processo contínuo em sua elaboração. Isso fez com que os dados e os argumentos aqui apresentados fossem aprofundados e revistos algumas vezes, a partir da releitura de certos trabalhos, da leitura de novos dados, materiais bibliográficos e científicos e da reflexão sobre estes. Além disso, quanto à primeira etapa da revisão, feita para destacar os elementos teóricos necessários para inferir sobre o tema, a evolução histórica destes conceitos foi deixada em segundo plano. Esta revisão foi deliberadamente restrita porque a intenção era apenas destacar os principais conceitos usualmente aceitos nestas áreas e necessários para a compreensão da argumentação aqui desenvolvida.

No que se refere à análise e apresentação dos resultados, foi assumida a postura de SILVA \& MENEZES (2001), à qual destaca que a análise dos dados deve ser realizada com a finalidade de atender aos objetivos propostos pela pesquisa, de modo a comparar e confrontar as informações colhidas, confirmando ou rejeitando os pressupostos da pesquisa. A análise propriamente dita encontra-se explicitada a partir da Parte II deste texto e consiste na reflexão sobre o tema aqui discutido.

O próximo item destaca a estrutura do trabalho e faz uma breve apresentação dos elementos que compõem cada um dos capítulos da dissertação. 


\section{E. A Estrutura do Trabalho}

A Parte I, composta por dois capítulos, apresenta conceitos e idéias centrais que guiaram a interpretação dos dados e deram sustentação para a maioria das considerações feitas a respeito da política industrial no processo de reestruturação produtiva ocorrido na cadeia automotiva brasileira.

O Capítulo I destaca elementos teóricos vindos da Economia e da Engenharia de Produção, fundamentais para a compreensão das características da Cadeia Automotiva e seu processo de reestruturação. O Capítulo II apresenta a definição de política industrial adotada neste trabalho, as principais visões a respeito do tema e os instrumentos de ação utilizados.

A Parte II, composta pelos Capítulos III e IV, consiste na análise sobre a política industrial realizada na reestruturação produtiva propriamente dita.

Com o objetivo de destacar aspectos relevantes sobre a cadeia automotiva nacional, o Capítulo III apresenta características relacionadas a esta estrutura, sua evolução ao longo do período estudado e alguns aspectos do processo de reestruturação produtiva ocorrido.

No Capítulo IV são discutidos os efeitos da política industrial adotada sobre este processo. Este capítulo utilizou os conceitos e as idéias desenvolvidas na primeira parte do trabalho para realizar a análise sobre os efeitos da política industrial em cada um dos momentos relevantes. 


\section{PARTE I - ELEMENTOS PARA A DISCUSSÃO}

Para realizar a análise aqui proposta foi preciso ter em mente certos conceitos e idéias fundamentais que possibilitaram uma melhor compreensão sobre as principais características da cadeia automotiva, sua estrutura, o papel da interação entre os diversos agentes e o padrão competitivo das organizações que a compõem.

Esta parte do trabalho possui o objetivo de apresentar os principais elementos conceituais que foram utilizados para sustentar as argumentações realizadas sobre a política industrial na cadeia automotiva brasileira, presentes na Segunda Parte.

O Capítulo I apresenta conceitos fundamentais para a compreensão da gestão econômica de sistemas produtivos, extraídos da Economia e da Engenharia de Produção. No Capítulo II é abordada a ação do Estado sobre a atividade produtiva ao apresentar e discutir a política industrial. 


\section{CAPÍTULO I - EMPRESA, CADEIA PRODUTIVA, MERCADO E REESTRUTURAÇÃO}

Quando são discutidos os efeitos de certas políticas de Estado sobre uma cadeia produtiva, a análise tende a se tornar necessariamente interdisciplinar. Ao discutir o impacto de temas ambientais sobre a função produção dos agentes que compõem uma cadeia, fica evidente que são necessários conhecimentos vindos de áreas distintas do saber, sendo que nesta dissertação foram destacadas a Economia e a Engenharia de Produção.

É na Economia, quer seja na microeconomia ou na macroeconomia, que as interações entre os agentes em um determinado ambiente e os efeitos dessas sobre a eficiência alocativa da sociedade ou de um determinado ramo de atividade são discutidas, porém, é na Engenharia de Produção que são abordados os aspectos técnicos necessários para tornar o processo de geração de bens e serviços cada vez mais eficiente e eficaz ao longo do tempo.

Sendo assim, o ambiente econômico afeta a produção, e as mudanças criadas com o desenvolvimento de novos processos produtivos e novos produtos e serviços são capazes de transformar o ambiente econômico, ampliando sua capacidade de criação de riqueza e bem estar.

Para estudar como a política industrial afetou a reestruturação produtiva na cadeia automotiva nacional foram necessários certos conceitos vindos tanto da área da produção quanto do ambiente que a circunda, por isso, temas e conceitos tratados na Teoria Econômica e na Engenharia de Produção foram utilizados para compor o arcabouço teórico que tornou possível este trabalho. Este capítulo foi elaborado com 
o objetivo de evidenciar os principais conceitos utilizados na análise, pertencentes a estas duas áreas do saber.

Com o objetivo de facilitar a exposição, os itens apresentam-se na forma de temas gerais. A partir do desenvolvimento destes temas é que são apresentados os conceitos teóricos e alguns argumentos a respeito.

No item 1.1, inicia-se a discussão a partir do tema empresa, o qual é comum às duas áreas do saber aqui destacadas. Tendo discutido a idéia de empresa e as questões relacionadas à função produção (intrínseca a este tema), o texto parte para o ambiente econômico em que as organizações estão inseridas com o desenvolvimento dos temas cadeia produtiva e mercado, nos itens 1.2 e 1.3, respectivamente.

O item final deste capítulo, 1.4, discute o tema reestruturação produtiva. Neste item buscou-se destacar a reestruturação como um processo natural no ambiente econômico e as questões ligadas a esse tema tanto no que diz respeito à Economia quanto à Engenharia de Produção.

\subsection{Empresa}

A maioria das discussões sobre o tema empresa costumam partir de duas questões que em geral encontram-se implícitas ou explícitas nas abordagens. Estas questões são: O que é uma empresa? Por que as empresas existem?

Se em um primeiro momento estas questões parecem triviais, devido à ampla presença das empresas como forma de organização produtiva na sociedade atual, antes de realizar um julgamento de valor é preciso considerar que ao longo da história várias respostas foram formuladas para estas perguntas, tanto na Engenharia de Produção quanto na Teoria Econômica, e também em outras áreas do saber. É interessante ter em mente que a definição de empresa sempre costuma ser uma idéia 
central quando se pretende desenvolver um referencial teórico para compreender o processo de produção dentro de um sistema econômico.

Para CHANDLER (1992), a empresa tem várias faces, que podem ou não ser enfatizadas nas elaborações teóricas a respeito. "Uma empresa é uma entidade legal que estabelece contratos com fornecedores, distribuidores, empregadores e, freqüentemente, com clientes. É também uma entidade administrativa, já que havendo divisão do trabalho em seu interior, ou desenvolvendo mais de uma atividade, uma equipe de administradores se faz necessária para coordenar e monitorar as diferentes atividades. Uma vez estabelecida, a empresa se torna um conjunto articulado de qualificações, instalações e capital líquido. Finalmente, em nome de lucros, empresas têm sido e são instrumentos de economias capitalistas para a produção de bens e serviços e para o planejamento e a alocação para a produção e distribuição futuras" (CHANDLER, 1992, p. 483).

A proposição de PENROSE (1959) é complementar, já que destaca que os teóricos fazem escolhas dentre múltiplos aspectos da empresa:

“Uma empresa [...] não é um objeto observável de maneira fisicamente separada de outros objetos, e é difícil de se definir a não ser com referência ao que faz ou ao que é feito em seu interior. Conseqüentemente, cada analista é livre para escolher quaisquer características da empresa nas quais esteja interessado, definir a empresa em termos destas características, e proceder de forma a chamar sua construção de “empresa"” (PENROSE, 1959, p.10, apud DANTAS et. al., 2002).

Ao partir destas observações é possível destacar que na Engenharia de Produção tende-se a se privilegiar o papel das empresas como uma função produção, o que deve ser visto com naturalidade já que é objeto desta área do saber o processo 
produtivo. SLACK et al. (1997) apresentam uma boa definição sobre a função produção e discutem o papel desta na realidade empresarial.

Para estes autores, "a função produção na organização representa a reunião de recursos destinados à produção de seus bens e serviços" (SLACK et al., 1997, p. 33). Eles destacam que qualquer organização (empresa, neste caso) possui uma função produção porque produz algum tipo de bem e/ou serviço. Entretanto, nem todos os tipos de organizações, necessariamente, denominam a função produção por esse nome, às vezes os termos produção, operação e até mesmo sistema de produção são apresentados como sinônimos da função produção. Além disso, SLACK et al. (1997) destacam que a função produção é central para a empresa, já que produz "os bens e serviços que são a razão de sua existência" (SLACK et al., 1997, p. 34), o que demonstra porque a área de produção toma este elemento como fundamental quando observa a empresa, porém, os próprios autores argumentam que tal função não é a única dentro da organização, mas também afirmam que as demais funções devem estar ligadas à função produção, "por objetivos organizacionais comuns", o que ressalta mais uma vez o papel central desta função empresarial, evidente na ótica da Engenharia de Produção.

Na Economia a função produção também é definida, ela se apresenta como um elemento fundamental na teoria do produtor (ou da produção), parte integrante da microeconomia tradicional (ou neoclássica). PINDIYCK \& RUBINFELD (2002) definem a função produção (ou função de produção) como "a relação existente entre os insumos do processo produtivo e o produto resultante", ou seja, "uma função que mostra o produto máximo que uma empresa pode obter para cada combinação especificada de insumos" (PINDIYCK \& RUBINFELD, 2002, p. 176). Tal definição 
não é distinta em sua essência da apresentada por SLACK et al. (1997) a diferença é que esta destaca o caráter otimizador, "do produto máximo", ligado à função produção. Sendo assim, existem dois aspectos implícitos na função produção das empresas e que precisam ser destacados: a eficiência e a eficácia.

Para a língua portuguesa, a palavra eficiência pode ser definida como a "ação ou virtude de produzir algum efeito", já a eficácia consiste "naquilo que produz o efeito desejado" (FERREIRA et al., 1999). Tais palavras às vezes costumam ser tidas como sinônimos, porém, é evidente que estes termos transmitem idéias distintas.

Segundo SANDRONI (1999, p.198), a eficácia significa "fazer o que necessita ser feito para alcançar determinado objetivo". Para esse autor, esse conceito é "distinto do de eficiência por se referir ao resultado do trabalho". Se for tomado como exemplo o uso da força de trabalho de um empregado, esta, só será eficaz, "se este trabalho ou o seu produto é adequado a um fim proposto". Dessa forma, o autor destaca que um trabalhador pode produzir um produto adequado (idealmente a um consumidor ou objetivo empresarial), mas se não realizar as tarefas correspondentes com eficiência, o resultado final poderia não ser visto como apropriado. O ideal seria que o resultado da tarefa executada pela força de trabalho fosse eficaz (adequada a um objetivo) e que a tarefa fosse realizada de maneira eficiente, ou seja, que fosse "feita a coisa certa de forma certa" (eficaz e eficiente).

Sendo assim, SANDRONI (1999) apresenta a relação entre os termos na própria definição destes, e visa salientar assim a distinção existente. No que diz respeito à idéia de eficiência, o autor destaca que esta consiste na "forma de realizar uma tarefa". Se, por exemplo, "um trabalhador realizar uma tarefa de acordo com as normas e padrões preestabelecidos, ele a estará realizando de forma eficiente", o que 
quer dizer que no conceito de eficiência não é examinado se aquilo que foi produzido com eficiência é eficaz, isto é, se o produto ou o resultado do trabalho está adequado a uma determinada finalidade proposta. O autor exemplifica tal distinção da seguinte forma: "se um médico realizar uma intervenção cirúrgica num paciente, poderá fazêlo com grande eficiência, mas se a intervenção tiver sido realizada no órgão errado, ela não terá a mínima eficácia" (SANDRONI, 1999, p. 198). O que demonstra que uma ação pode ser eficiente sem ser eficaz (e que o contrário também é verdade, como já foi apresentado).

Estes dois critérios estão presentes nas definições apresentadas sobre função produção, por exemplo, quando se trata das combinações de fatores (eficiência) e a máxima utilização de recursos (eficácia). Portanto, podem ser utilizados para analisar a função produção nas empresas, porém, qual seria a abrangência da função de produção na empresa?

Voltando à definição de função produção apresentada por SLACK et al. (1997), nota-se que as fronteiras da função produção podem ser discutidas a partir de uma ótica "restrita" ou "ampla". "Uma definição organizacional restrita das fronteiras da função produção excluiria todas as atividades compartilhadas com quaisquer outras funções", enquanto que uma "definição mais ampla da produção incluiria todas as atividades que possuíssem qualquer conexão com a produção de bens e serviços - na prática, todas as atividades, com exceção das de marketing/vendas e contabilidade/finanças" (SLACK et al., 1997, p. 34). 
Estas duas abordagens sobre a função produção são ilustradas na seguinte figura:

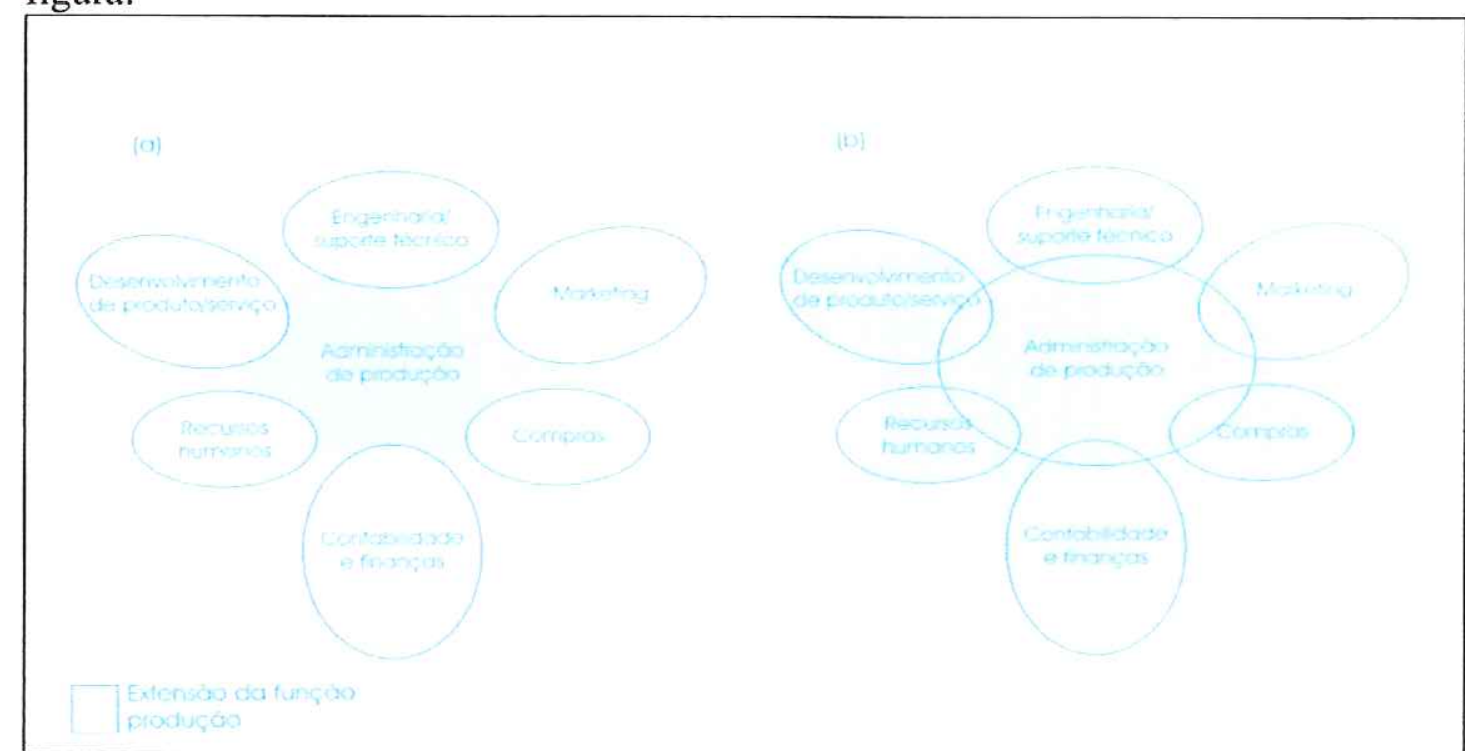

FIGURA 1.1: Fronteiras da função produção: (a) definição restrita, (b) definição ampla.

Fonte: SLACK et al., 1997, p. 36.

SLACK et al. (1997) destacam textualmente que utilizam a definição relativamente ampla em suas abordagens, já que com esta é possível discutir tópicos e assuntos que têm implicações diretas sobre a preocupação central do trabalho elaborado por eles, ou seja, a razão de existência da organização, que é vista como sendo a produção de bens e serviços (SLACK et. al., 1997, p. 34). A pesquisa aqui realizada acompanhou os passos seguidos por esses autores neste sentido, ou seja, adotou a definição ampla para a função produção.

Ao observar a empresa a partir da função produção, é possível destacar o processo de transformação ocorrido nesta, a partir da operacionalização da função produção, a qual é vista no modelo de transformação. Também é possível destacar aquilo que compõe a menor porção organizada de tarefas dentro das empresas, ou seja, suas atividades, para, com isso, compreender o que significado e o papel da tecnologia na empresa. 
Com estes conceitos em mente parte-se para uma observação mais ampla, na qual são vistas diversas abordagens sobre a empresa oriundas da teoria econômica, as quais realizam observações sobre a empresa e considerações ligadas às interações da organização com o ambiente econômico que a circunda.

Quando se utiliza o termo processo de transformação, costuma-se referir ao conjunto de atividades utilizadas para transformar recursos e insumos (também conhecidos como inputs), para mudar o estado ou condição destes e com isso gerar bens e/ou serviços (também conhecidos como outputs). O modelo de transformação é uma demonstração da forma como o processo de transformação ocorre na empresa, independente das atividades que ela executa. Ele pode ser representado a partir da seguinte figura:

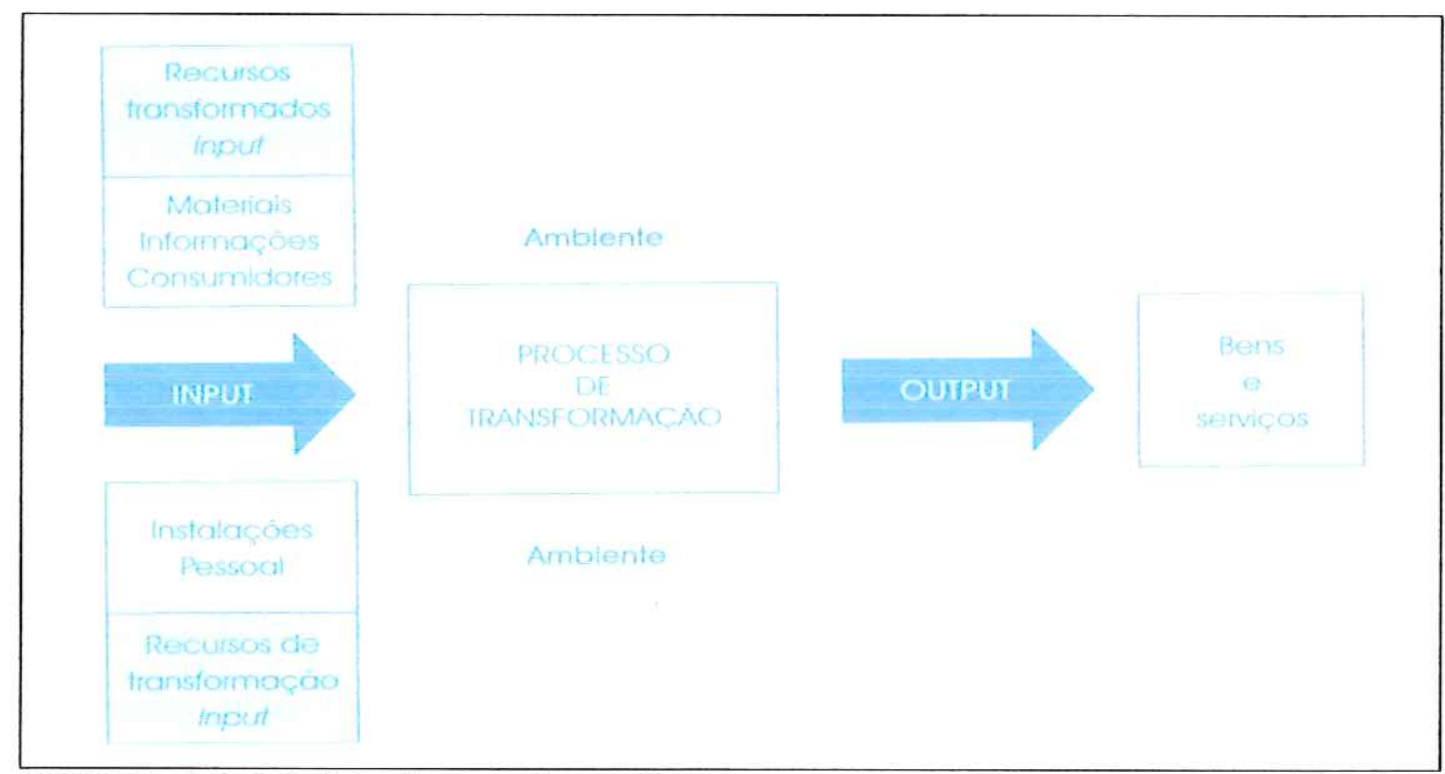

FIGURA 1.2: Modelo de transformação.

Fonte: SLACK et. al., 1997, p. 36.

Ao observar o modelo de transformação apresentado por SLACK et al. (1997) nota-se que os inputs são divididos em dois grupos: os recursos transformados e os recursos de transformação. Os recursos transformados são "aqueles que são tratados, transformados ou convertidos de alguma forma" e os recursos de 
transformação são "aqueles que agem sobre os recursos transformados" para, no processo de produção, gerar bens e/ou serviços (outputs). Nota-se que tanto os recursos transformados, quanto os recursos de transformação são vistos na Economia como fatores de produção, ou seja, os recursos necessários para realizar o processo de produção ${ }^{2}$

Este modelo geral de transformação, como já foi dito, ilustra o processo de transformação e, portanto, a função produção, para qualquer tipo de empresa, independente das atividades que ela executa e dos bens e/ou serviços que ela disponibiliza à sociedade, porém, cada empresa, na prática, apresenta diferenças em seus processos de transformação, se as compararmos com outras que produzam bens e/ou serviços similares. Por que isso ocorre? A resposta mais correta é que cada empresa possui uma função produção que lhe é particular, já que os processos de transformação empregados apresentam variações entre uma firma e outra.

Para que seja possível compreender este ponto é necessário ter em mente a idéia de tecnologia. A tecnologia é definida segundo VASCONCELLOS (2002, p. 119), como um inventário de métodos de produção conhecidos, ou seja, as maneiras disponíveis relacionadas à "como produzir" um bem e/ou serviço qualquer. Esta definição encontra-se diretamente ligada ao processo de transformação, consiste no detalhamento deste processo. Até este momento a tecnologia era vista como dada na função produção, já que não havia sido discutido o modo como os fatores de produção são combinados dentro da empresa. Porém, a partir de agora é possível destacar que a tecnologia está associada aos inputs vistos como recursos de

\footnotetext{
${ }^{2}$ Nos principais modelos econômicos os fatores de produção dividem-se em três grandes grupos: Terra (T), Capital $(\mathrm{K})$ e Trabalho $(\delta)$. Em certos casos também é comum observar o fator MatériaPrima (Mp), destacado. Deve ficar claro que estes grandes grupos podem ser subdivididos sobre vários critérios com o objetivo de dar maior realismo aos modelos.
} 
transformação e também ao processo de transformação empregado, o que faz com que seja necessário destacar os aspectos ligados aos produtos (ou serviços) e os aspectos dos processos que deram origem a esses bens. Esses aspectos são destacados nos conceitos de tecnologia de processo e tecnologia de produto.

Uma tecnologia de processo, segundo SLACK et. al. (1997, p. 252), é qualquer artefato, máquina ou equipamento que ajuda a transformar, materiais, informações ou consumidores de forma a agregar valor e atingir objetivos estratégicos de produção, já uma tecnologia de produto, seria a forma como a necessidade de um indivíduo é atendida por um produto (ou serviço).

Por exemplo, a tecnologia de produto em um DVD é a forma como ele converte sinais vindos da leitura do disco em imagens que serão transmitidas na televisão, já a tecnologia de processo consiste nas máquinas-ferramentas que fizeram os componentes de metal, as máquinas que montaram os componentes de metal, as máquinas que montaram os componentes eletrônicos nas placas de circuitos impressos, as máquinas que deram forma e ligaram as folhas de metal para formar o gabinete e os robôs e equipamentos utilizados para montar os componentes.

Os autores destacam que na manufatura é uma questão até certo ponto simples separar a tecnologia de processo da tecnologia de produto, mas que nos serviços ou mesmo em certos casos específicos de manufatura é possível encontrar dificuldades nesta separação.

As tecnologias de processo, caso tenham a mesma eficácia, podem ser diferentes sob o ponto de vista da eficiência. Para distinguir melhor esta diferença, convém definir eficiência técnica e eficiência econômica. 
Uma tecnologia eficiente sob o ponto de vista técnico é aquela que, dado pelo menos dois ou mais processos de produção, permite produzir uma mesma quantidade de produto, utilizando uma menor quantidade física de fatores de produção, já uma tecnologia economicamente eficiente é aquela que entre dois ou mais processos produtivos, permite produzir uma mesma quantidade de produto, com menor custo de produção (VASCONCELLOS, 2002).

A tecnologia não é estática ao longo do tempo. No que diz respeito à importância relativa dada aos dois tipos de tecnologia aqui definidos, SLACK et. al. (1997) afirmam que à medida que o produto progride ao longo do seu ciclo de vida, a importância relativa de cada uma das tecnologias se modifica. No primeiro momento, o da inserção no mercado, a tecnologia de produto tende a se mostrar mais relevante, a partir do momento em que o produto vai se tornando maduro, a tecnologia de processo vai ganhando cada vez mais importância.

Este ponto apresentado no parágrafo acima merece atenção especial, já que para explicar a mudança da importância relativa entre um tipo de tecnologia e outro é preciso definir um tema vital para algumas abordagens sobre a empresa, a inovação tecnológica.

A inovação tecnológica consiste em mudanças qualitativas ocorridas ao longo do tempo nos produtos e processos produtivos capazes de gerar diferenciações vistas pelos consumidores como melhorias, mudanças relacionadas à elevação dos níveis de eficiência e eficácia atingidas e reduções de custos. Elas podem ser radicais, ou seja, capazes de modificar por completo a forma como o processo produtivo e o produto se apresentam, criando assim processos e/ou produtos relativamente novos pela ótica 
do consumidor ou do produtor, ou incrementais, nas quais a inovação visa apenas melhorar aquilo que já existe sob algum ponto de vista específico.

$\mathrm{Na}$ Economia os autores evolucionistas (ou neo-schumpeterianos), são os que dão maior ênfase ao papel da tecnologia nas empresas, como será visto em breve. A teoria econômica apresenta uma diversidade de respostas sobre a definição da empresa e seus objetivos. Isso ocorre porque cada uma das abordagens teóricas existentes busca destacar aspectos particulares desta forma de organização, alicerçados nas considerações presentes nestas abordagens sobre o funcionamento do sistema econômico (DANTAS et al., 2002, p. 24). Para este trabalho convém destacar as visões relacionadas à microeconomia tradicional (também conhecida como neoclássica), a qual consiste na ortodoxia do pensamento econômico e também a abordagem evolucionista e institucionalista, as quais fazem parte do grupo de pensamento tido como heterodoxo na Economia.

$\mathrm{Na}$ abordagem neoclássica sobre o tema empresa, a mais difundida entre todas, o centro da teoria é o problema da alocação de recursos escassos a necessidades ilimitadas. Segundo DANTAS et al. (2002, p. 26), essa escola utiliza a leis dos rendimentos ${ }^{3}$ para discutir o valor das mercadorias como a solução de um problema alocativo.

A empresa é, assim, o local onde se combinam os fatores de produção de maneira a gerar os produtos (ou serviços), sendo a produção sujeita às leis dos rendimentos, que são discutidas primordialmente no interior de cada unidade de

\footnotetext{
${ }^{3}$ A lei dos rendimentos, segundo SANDRONI (1999), pode ser definida como a variação obtida na produção devida ao incremento na utilização dos fatores variáveis no processo produtivo e mantendose fixa a quantidade dos demais fatores. Tal variação pode apresentar rendimentos crescentes, decrescentes ou constantes ao longo de um período específico e consiste numa observação de curtoprazo.
} 
produção isolada. Desta forma, esta abordagem considera a discussão feita sobre a função produção, já que discute o papel desta na empresa.

A abordagem da microeconomia neoclássica admite como objetivo fundamental da empresa o lucro econômico. As principais hipóteses utilizadas são que as empresas estão inseridas em condições de concorrência perfeita, os mercados tendem ao equilíbrio a partir da relação entre oferta e demanda, a qual determina os preços, a capacidade dos agentes para solucionar problemas organizacionais é ilimitada (daí o caráter otimizador da função produção) e a informação disponível sobre a realidade na qual a empresa está inserida é plena e sem custo. Além disso, a abordagem sobre a empresa na microeconomia tradicional não considera em seu cerne aspetos institucionais ou tecnológicos, os quais são vistos como dados e, com isso, deixa de levar em conta elementos de grande importância no que diz respeito a explicações sobre desempenho econômico das diversas empresas no ambiente em que estão inseridas.

Mesmo com estas hipóteses restritivas esta abordagem é relevante ao destacar o papel da empresa como o agente produtivo da sociedade e apresentar esse agente sujeito aos interesses desta, os quais são explicitados a partir da demanda por bens e serviços surgida no mercado (tema a ser discutido no próximo item). O problema é que ao utilizar tais hipóteses esta visão se distancia da realidade e perde capacidade analítica no que se refere a comportamentos estratégicos das empresas em relação ao meio em que elas estão inseridas.

AZEVEDO (1998, p. 212), ao criticar a abordagem da microeconomia neoclássica, destaca que a estrutura organizacional é relevante já que no dia/dia das organizações: “(a) a informação necessária para gerir uma empresa não é completa; 
b) os contratos internos e externos à firma apresentam custos ao ser implementados;

c) a adaptação a contingências não antecipadas é variável conforme a forma organizacional adotada". Assim, para esse autor, é necessário que a empresa se organize de modo a lidar eficientemente com esses problemas informacionais, contratuais e/ou de adaptação, que, antes de serem exceção, na realidade caracterizam melhor a problemática enfrentada pela maioria das empresas contemporâneas.

Tendo em vista estas constatações é possível identificar no âmbito da Economia e, de uma forma mais ampla, nas diversas visões sobre a organização produtiva, como é o caso da Engenharia de Produção, o que se convencionou chamar de teorias sobre a Organização Industrial.

A Organização Industrial, segundo AZEVEDO (1998), pode ser vista como uma contraposição à visão microeconômica tradicional. Agrupa diversas teorias em um corpo teórico não consolidado. Sua origem ocorre na década de 30, com as contribuições de HALL \& HITCH (1939), MASON (1939) e COASE (1937), as quais, partindo de diferentes problemáticas e procedimentos, apresentam como ponto em comum o fato de terem sido as visões que possibilitaram o relaxamento dos pressupostos neoclássicos apresentados anteriormente.

Para a visão neoclássica, a empresa tem como objetivo a maximização do lucro e possui pleno conhecimento de suas funções de custo e de demanda, como já foi destacado. Os estudos que deram origem à Organização Industrial questionaram exatamente esse princípio, a partir da observação do processo de decisão empresarial.

PENROSE (1959) destacou que a empresa reúne e combina recursos, mas esta função contrasta com a empresa neoclássica porque não há relação biunívoca 
entre um recurso e os serviços que dele se podem obter. Os serviços dos recursos dependem do ambiente (da empresa) em que tais recursos são utilizados, com especial importância para os conhecimentos utilizados quando do seu emprego. As empresas, portanto, encerram experiências e conhecimentos acumulados ao longo de suas existências, o que faz de cada empresa "um exemplar único" nas palavras da autora, resultante de sua trajetória específica, dos problemas que enfrentam, das estratégias e soluções que escolhem.

A abordagem institucionalista realiza uma observação da empresa distinta da microeconomia neoclássica; tal concepção toma a definição de empresa desenvolvida por COASE (1937).

Em 1937, COASE buscou apresentar uma visão mais ampla sobre a firma. Ele observava que as firmas não poderiam ser caracterizadas apenas como uma função de produção, devido a sua complexidade. A partir disso, ele ambicionou compreender o escopo, a abrangência e os limites da empresa.

Neste intuito, o autor observa que as transações entre os agentes econômicos apresentavam custos dos mais diversos e que tais transações poderiam ser realizadas utilizando-se de diferentes arranjos organizacionais, como o mercado, contratos de longo prazo ou mesmo internamente à firma. Este último arranjo não era visto apenas como uma capacidade dada pela função produção, mas sim como uma forma alternativa de se transacionar em comparação ao mercado, o que abre espaço para diversas discussões ${ }^{4}$.

\footnotetext{
${ }^{4}$ Uma discussão que agora pode ser desenvolvida, a partir desta constatação, é a idéia de comércio intrafirma, por exemplo.
} 
Destas constatações COASE (1937) nota que o elemento que definiria o escopo e os limites de uma empresa seria o modo como a organização desempenha suas funções de forma alternativa ao mercado. Internalizar ou externalizar transações seriam decisões tomadas com relação ao ambiente e aos objetivos da empresa (que, além do lucro econômico, poderiam envolver diversos pontos considerados como estratégicos para a empresa, como, por exemplo, crescimento da firma, conquista de novos mercados, diversificação, entre outros objetivos).

O trabalho de COASE (1937) possui a virtude de enriquecer as visões sobre a empresa. Ao abordar as restrições econômicas provocadas pelos custos das transações, ele torna possível a inserção de elementos antes considerados exógenos à análise econômica do sistema produtivo, como, por exemplo, a estrutura organizacional da firma e os diversos contratos estabelecidos (WILLIANSON, 1985).

A visão institucionalista toma como fundamental o papel das diversas instituições e, de forma particular, dos diversos arranjos organizacionais sobre a eficiência e a eficácia econômica e social (AZEVEDO, 1998).

O principal autor a abordar esta problemática do ponto de vista da Organização Industrial é WILLIAMSON (1985). Ele parte da análise de COASE (1937) sobre a empresa e amplia alguns pontos anteriormente desenvolvidos por esse autor, o que disponibilizou, desta forma, uma explicação para o surgimento e a magnitude dos custos de transação.

CHESNAIS (1996, p. 83), coloca que o eixo do texto de WILLIAMSON (1985), “consiste em demonstrar que as grandes dimensões das companhias contemporâneas e certo grau, mais ou menos elevado, de concentração, não passam 
de conseqüências inevitáveis de um universo econômico com informação imperfeita e com freqüentes comportamentos oportunistas, os quais tornam os mercados inaptos a cumprir seu papel, apesar de ser esta a instituição fundamental do sistema econômico atual".

WILLIAMSON (1985) demonstra que a magnitude dos custos de transação é variável conforme sejam as características de uma determinada transação. Como características fundamentais ele observa três dimensões: a freqüência das transações, a incerteza envolvida e a especificidade dos ativos - as quais determinam o escopo da empresa e suas op̧̧ões estratégicas.

Como principais contribuições desta visão sobre os estudos recentes ligados à Organização Industrial, deve-se destacar suas inferências relacionadas à questão da integração vertical e dos contratos, as quais apresentam conclusões distintas e até mesmo polêmicas quando levadas ao campo da política econômica.

Uma corrente de teoria econômica em que a empresa é vista como agente que acumula capacidades organizacionais é a dos evolucionistas (ou neoschumpeterianos). No sentido de compreender as principais observações sobre a empresa desta visão, convém destacar os trabalhos de DOSI (1984) e também de NELSON \& WINTER (1982). Além destes, o referencial teórico desenvolvido pela escola evolucionista tomou como marco teórico de referência as discussões realizadas por SCHUMPETER, principalmente nos livros publicados originalmente em 1911 e 1942 por esse autor.

Para os autores evolucionistas, ao invés da escolha racional e permanentemente renovada, implícita na abordagem sobre empresa da corrente principal da teoria econômica, as empresas se comportam de acordo com rotinas 
cristalizadas através de sua experiência, que possuem o papel de coordenar a atividade interna dos membros da empresa, ao mesmo tempo em que encerram o conhecimento da organização, à semelhança de um código genético.

A discussão das rotinas enfatiza um aspecto central do comportamento das empresas: o de que não bastam os equipamentos e seus manuais para sua utilização; a empresa não é uma planta operada com custos variáveis na forma de trabalho que pode ser contratado ou demitido; as rotinas encerram o conhecimento da empresa, e incluem a produção, transmissão e interpretação das informações provenientes do ambiente externo e as geradas no interior da empresa. Sendo em grande parte conhecimento tácito e não-formal, é adquirido através da participação na atividade rotineira.

Para esta abordagem, elementos como inovação tecnológica, incerteza e competitividade são fundamentais no que se refere a explicações relacionadas ao desenvolvimento econômico e, de maneira específica, às questões ligadas à empresa. Como fica claro a partir da leitura de NELSON \& WINTER (1982), e também de SHUMPETER (1942), em ambientes em que há uma elevada incerteza quanto aos acontecimentos futuros, não é possível a previsão em relação aos acontecimentos relevantes ou mesmo das conseqüências de atos individuais.

Para essa visão, o nível de incerteza em um ambiente produtivo é determinado fundamentalmente pelo ritmo de progresso técnico, sendo esse entendido como a inovação tecnológica vista em sua forma ampla. Além disso, em um ambiente incerto, o mercado assume um papel fundamental distinto do apresentado pela abordagem neoclássica, o qual será discutido posteriormente. 
Para concluir este item, baseado no que foi apresentado sobre o tema empresa, é possível destacar que ao discutir a função produção pode-se abordar aspectos fundamentais referentes à organização interna da firma. A visão evolucionista, ao dar ênfase a questões como inovação tecnológica, incerteza e competitividade, desenvolve um poderoso instrumental teórico capaz de garantir relevantes contribuições aos estudos que discutem a dinâmica competitiva atual, e a abordagem institucionalista, ao considerar a empresa a partir da análise de COASE (1937), desenvolvida por WILLIAMSON (1985), facilita a compreensão das interações existentes entre a empresa e os demais agentes econômicos.

Devido às características do trabalho aqui realizado, a ênfase adotada sobre os conceitos e abordagens aqui explicitados mostrou-se necessária e interessante, já que garantiu um arcabouço teórico adequado para a realização dos objetivos aqui propostos, como poderá ser notado a partir da Segunda Parte desta dissertação.

Como a discussão feita até o momento foi sobre o tema empresa e a dissertação trata da cadeia automotiva nacional, cabe aqui destacar o porquê desta opção metodológica, pois, afinal, já que o conceito de empresa foi discutido em linhas gerais, o trabalho poderia ter partido diretamente para a análise destas e não da cadeia automotiva.

Um problema teria surgido se o trabalho aqui apresentado abordasse diretamente as empresas que compõem a cadeia automotiva - seria necessário, sob o ponto de vista metodológico, que na discussão fossem consideradas as realidades de todas as empresas montadoras de automóveis e as demais empresas e agentes relacionados à fabricação e comercialização destes veículos, suas particularidades e interações ao longo do período estudado (o que poderia tornar o trabalho aqui 
proposto inviável), ou, se a discussão não fosse capaz de abordar todas as empresas, caso ela, ainda assim, partisse do tema empresa, seria necessário delimitar uma amostra suficientemente ampla de empresas que pudesse ser vista como significativa - sob o ponto de vista estatístico - o que iria demandar recursos e procedimentos metodológicos distintos daqueles empregados nesta dissertação de mestrado.

Tendo em mente estas observações e a partir da concepção de empresa buscou-se uma visão agregada que tornasse possível uma melhor compreensão dos impactos gerais da política industrial sobre todas as empresas ligadas à montagem de automóveis e comerciais leves, juntamente com os demais agentes produtivos relacionados a essas organizações. Portanto, para atender a esse objetivo, foi adotado o conceito de cadeia produtiva, utilizado para derivar o que seria a cadeia automotiva brasileira - o objeto analisado neste trabalho.

\subsection{Cadeia produtiva}

As cadeias produtivas são vistas por DANTAS et al. (2002) como extensões da idéia de setor econômico que privilegiam aspectos concorrenciais. À medida que a competitividade das empresas depende do seu meio ambiente imediato, como fica evidente nas abordagens institucionalista, a arena concorrencial se amplia. Ela deixa de ser apenas a dos mercados imediatos de venda de mercadorias/serviços e aquisição de insumos, para também incorporar mercados acima e abaixo da cadeia em que a empresa está atuando (DANTAS et al., 2002, p.36).

O mesmo autor destaca um ponto de suma importância para esta pesquisa: as cadeias produtivas resultam da crescente divisão do trabalho e maior interdependência entre os agentes econômicos. Por um lado, as cadeias são criadas pelo processo de desintegração vertical e especialização técnica e social. Por outro 
lado, as pressões competitivas por maior integração e coordenação entre as atividades, ao longo das cadeias, ampliam a articulação entre os agentes.

A cadeia produtiva é, portanto, um conjunto de etapas consecutivas pelas quais passam e vão sendo transformados e transferidos os diversos insumos. Esta definição abrangente permite incorporar diversas formas de cadeias sendo a cadeia automotiva, apresentada neste trabalho, um exemplo nesta definição.

Como a cadeia produtiva vai além da empresa, já que destaca a interação entre diversas empresas, o termo acaba abrangendo a todas as firmas envolvidas no processo de geração de um determinado bem - no caso desta pesquisa os automóveis e comerciais leves - isso garante uma análise agregada, que se mostra adequada para os objetivos aqui estabelecidos.

\subsection{Mercado}

Para a microeconomia neoclássica o mercado é tratado como um espaço abstrato em que se encontra a oferta e a demanda, o produto é visto como algo absolutamente bem definido e, portanto, perfeitamente distinguível na análise dos consumidores. Neste sentido, o mercado reflete, em última instância, o conjunto de empresas produtoras desta mercadoria, de forma que a cada indústria corresponde um mercado. Em conseqüência, o conceito de indústria assumido por essa corrente expressa espaços delimitados e estanques de competição, onde, a partir das forças da oferta e da demanda se chega a situações de preços de equilíbrio, as quais permaneceriam, mesmo se fosse utilizado o conceito de cadeia produtiva já explicitado (DANTAS et al., 2002, p.36).

Ao se utilizar uma visão heterodoxa, o mercado corresponde à demanda por um grupo de produtos substitutos próximos entre si. Para uma empresa diversificada, 
no entanto, a idéia de mercado envolve também outros espaços concorrenciais em que pode atuar, definidos como áreas de comercialização por PENROSE (1959). A indústria, por seu turno, é definida pelo grupo de empresas voltadas para a produção de mercadorias que são substitutas próximas entre si e, desta forma, fornecidas a um mesmo mercado. Da mesma forma que para a noção de mercado, para uma empresa diversificada a indústria pode representar um conjunto de atividades que guardam algum grau de correlação técnico-produtiva, constituindo um conjunto de empresas que operam métodos produtivos semelhantes, incluindo-se em uma mesma base tecnológica - com isso, a tecnologia e as formas de organização produtivas desenvolvidas pelos agentes passam a ser vistas como um importante elemento de análise.

Neste ponto apresenta-se o papel das instituições e dos arranjos organizacionais. A abordagem institucionalista destaca que devido à incapacidade do mercado em encontrar sempre soluções ótimas - preços de equilíbrio, por exemplo as instituições se colocam como as organizadoras das "regras do jogo", tendo a função de restringir o comportamento oportunista dos agentes e por conseqüência reduzir os custos de transação envolvidos nos contratos existentes, tanto no mercado, quanto internos à firma ou cadeia produtiva.

Os evolucionistas destacam que o mercado, a partir da competição, cumpre o papel de selecionar entre os agentes produtivos os melhores arranjos organizacionais e as melhores tecnologias. Essa capacidade fundamental do mercado em relação ao sistema econômico, dada pela competitividade, é chamada pelos evolucionistas de processo de destruição criadora, segundo SCHUMPETER (1942). 
Cabe destacar neste ponto, o conceito de trajetória tecnológica, apresentado por DOSI (1988). Para esse autor, critérios econômicos agiriam de forma a selecionar algumas direções no avanço da tecnologia e excluir outras definindo assim uma trajetória. Além disso, uma dada trajetória poderia abrir novas oportunidades de emprego da técnica em certas direções e excluir outras dos campos de análise, impondo assim, o direcionamento do progresso técnico dentro de um paradigma definido, o qual o autor chama de paradigma tecnológico.

DOSI (1988) nota que nem sempre certos avanços da ciência e suas relações com o desenvolvimento tecnológico dependem dos mecanismos econômicos. Devido a essa situação e a outros fatores, há espaço para o surgimento de um novo paradigma tecnológico, que, ao ser adotado, implicaria na criação de complementaridades entre diferentes técnicas e possibilitaria novas relações de dependência entre as indústrias possibilitando, talvez, desenvolvimento econômico.

Outro ponto que merece ser destacado é o possível surgimento de economias externas não desprezíveis, as quais são benefícios oriundos da nova tecnologia que não são apropriados aos bens e/ou serviços a partir do sistema de preços do mercado. Para os evolucionistas, as organizações buscarão apropriar e utilizar estas externalidades em seu escopo, sempre que essas se mostrarem de maneira positiva.

Para concluir, deve ficar claro que no processo de criação de rotinas existe implícito o processo de aprendizado. As novas rotinas incorporam a experiência passada, modificando as formas organizacionais estabelecidas, o que faz com que a abordagem evolucionista se mostre essencialmente dinâmica. 


\subsection{Reestruturação produtiva}

Para encerrar esse capítulo é preciso destacar a idéia de reestruturação produtiva, a qual se encontra associada à mudança tecnologia, principalmente àquela relacionada a transformações de processos produtivos que levam a sociedade a ganhos de eficiência e eficácia.

O processo de reestruturação produtiva é natural e ocorre constantemente, já que ao longo da utilização de uma determinada técnica há sempre o surgimento de novos meios, novas tecnologias de produto e/ou de processo, as quais tendem a mostrar mais eficiência e/ou eficácia se comparadas àquelas que lhe antecederam. $\mathrm{O}$ que é interessante destacar é que este processo se intensifica em certos períodos de tempo.

Para compreender o processo de reestruturação produtiva convém dar ênfase aos conceitos de paradigma tecnológico e trajetória tecnológica, já apresentados na discussão sobre a abordagem evolucionista. Além destes conceitos, deve-se ter em mente que são as mudanças no ambiente econômico, capazes de afetar os diversos mercados e cadeias produtivas, que determinam em grande parte o ritmo de reestruturação produtiva observado. Caso essas mudanças ocorram de forma ampla, a reestruturação será intensa, caso contrário, não. 


\section{CAPÍTULO II - POLÍTICA INDUSTRIAL}

A ação do Estado sobre a atividade produtiva, quer seja como regulador, produtor ou promotor, é um dos temas que mais geram controvérsias na teoria econômica. Isso ocorre porque tanto as diversas correntes do pensamento econômico quanto eventos históricos apresentam argumentos positivos e outros negativos sobre o papel do Estado na economia e sobre a interação deste com os demais agentes (empresas e famílias).

Ao longo da história é possível notar que a postura sobre o papel do Estado varia entre momentos de grande intervenção e outros em que prevalecem atitudes liberais. Como destaca FERRAZ, MENDES \& KUPFER (2002, p. 549) “a discussão sobre as relações entre Estado e mercado surge quando se questiona a efetividade do sistema privado em alocar recursos econômicos escassos para os fins desejados de uma sociedade, em momentos específicos do tempo".

O objetivo deste capítulo é definir e discutir o tema política industrial. Isso se faz necessário já que tal política representa a forma como o Estado age sobre a atividade produtiva.

No primeiro item (2.1) será definida a política industrial. Logo após, serão destacadas as principais visões relacionadas a esse tema (item 2.2) e no último item, 2.3, serão apresentados os principais instrumentos utilizados pelo Estado para promover a Política Industrial.

\subsection{Política Industrial: Definição}

FERRAZ, MENDES \& KUPFER (2002, p. 545) apresentam a seguinte definição sobre Política Industrial: 
"Do ponto de vista conceitual, política industrial deve ser entendida como o conjunto de incentivos e regulações associadas a ações públicas, que podem afetar a alocação inter e intra-industrial de recursos, influenciando a estrutura produtiva e patrimonial, a conduta e o desempenho dos agentes econômicos em um determinado espaço nacional” (FERRAZ, MENDES \& KUPFER, 2002, p. 545).

Tal definição, mesmo sendo clara e correta, pode ser vista como extremamente ampla por alguns. Isso ocorre porque a política industrial, diferente de outras políticas econômicas, mostra-se como uma ação do Estado sobre os agentes produtivos que utiliza vários instrumentos com o objetivo de influenciar as decisões econômicas quanto à alocação dos recursos para, com isso, melhorar a utilização desses pelas empresas e tornar possível o desenvolvimento econômico.

No trabalho de BEDÊ (1996, p.5), é destacado o porquê da amplitude nas definições sobre política industrial:

"Provavelmente, isto se deve ao fato da sistematização dos argumentos teóricos dessa área ser bastante recente. Além disso, as políticas industriais fazem uso de um conjunto muito variado de instrumentos que originalmente encontram-se na esfera das demais políticas públicas, tais como: compras preferenciais do Estado, taxas de juros subsidiadas, acesso facilitado ao câmbio, proteção ao mercado doméstico e regimes especiais de importação".

Como a política industrial consiste numa ação do Estado sobre a economia, a própria definição de política industrial não fica imune às questões ideológicas que envolvem esta relação. Sendo assim, além das definições anteriores, que se caracterizam pela amplitude, é possível notar a existência na literatura de definições 
mais pontuais, às quais se vinculam à microeconomia tradicional e à postura desta sobre a intervenção do Estado na economia.

Um bom exemplo de definição de Política Industrial relacionada a esta vertente do pensamento econômico é apresentada por KRUGMAN \& OBSTFELD (1988). Esses autores destacam que a política industrial seria o conjunto de esforços governamentais para encorajar o movimento de recursos em direção a um setor particular, visto como importante para o crescimento econômico futuro, às expensas dos demais setores da economia.

O relatório do Banco Mundial de 1993, também apresenta uma definição de política industrial caracterizada pelo enfoque mais restrito, se comparada àquelas apresentadas anteriormente, porém, a diferença é que são destacados os instrumentos dessa política como ações do Estado sobre a capacidade de aprendizado, a inovação tecnológica e atitudes que visem o emparelhamento (catching up) das atividades produtivas de uma nação às melhores práticas internacionais. Sendo assim, a política industrial poderia ser definida como os esforços para alterar a estrutura industrial vigente, visando o crescimento baseado na produtividade, via processos de aprendizado, inovação tecnológica ou busca das melhores práticas (WORD BANK, 1993).

Conforme destaca SUZIGAN (1998) apud JOHNSON (1984), CORDEN (1980), ADAMS \& BOLLINO (1983) e outros, a política industrial é vista como "uma expressão abrangente de medidas e programas que direta ou indiretamente afetam o setor industrial". Sendo assim, esses autores adotam uma definição ampla em contraposição às visões pontuais. 
O que é interessante notar no texto de SUZIGAN (1998) é que, ao apresentar a política industrial como uma expressão abrangente de programas, o autor, logo no momento subseqüente, busca elencar o conjunto de instrumentos relacionados a tal política. Nas palavras do autor "considera-se como parte de uma política (ou estratégia) industrial os seguintes elementos: planejamento geral indicativo, formalização de diretrizes e objetivos, organização institucional específica, articulação com a política macroeconômica, targeting de indústrias ou tecnologias específicas, instrumentos e políticas auxiliares (políticas de comércio exterior, financiamento, políticas de fomento, políticas de regulação e competição), investimentos em infra-estrutura econômica e de ciência e tecnologia, sistema educacional e treinamento de mão-de-obra e formação de recursos humanos especializados" (SUZIGAN 1998, p. 01).

Ao adotar o ponto de vista amplo em contraposição ao enfoque microeconômico tradicional, visto como restrito, SUZIGAN (1998) justifica sua escolha da seguinte forma:

"Este enfoque restrito, embora melhor justificado analiticamente como forma de intervenção para corrigir market failures, é objeto de fortes controvérsias sob o argumento de que favorece o surgimento de atividades e/ou empresas meramente rentistas. Por isso, segundo alguns autores, deveria ser preterido em favor de medidas de cunho horizontal, que não discriminem setores ou indústrias" (SUZIGAN, 1998, p.01).

Neste ponto é interessante uma observação atenta sobre os elementos convergentes nas definições apresentadas até aqui, afinal, mesmo existindo a polêmica entre diversos autores, que será debatida em maior profundidade no item 
que discute as visões que norteiam a política industrial, é evidente que são os elementos convergentes que tornam possível uma definição coerente sobre o tema, capaz de sustentar as análises apresentadas neste trabalho.

É natural que as definições abrangentes englobem os elementos das visões pontuais, isso fica claro se confrontarmos, por exemplo, a visão de SUZIGAN (1998), com a definição do Banco Mundial (1993). SUZIGAN (1998), ao elencar instrumentos de política em sua definição, não deixa de incluir os elementos destacados pelo Banco Mundial (1993), a diferença é que, além destes, ele trata de pontos que superam uma possível intervenção realizada no sentido restrito de corrigir falhas de mercado (market failures).

Em todas as definições aparece o papel do Estado em destaque, e a ação deste intervindo sobre os agentes produtivos. Os instrumentos de intervenção e o porquê da ação deste podem variar dependendo da linha de pensamento seguida, porém, este é o ponto fundamental a ser destacado nas definições sobre política industrial, ou seja, tal política é uma ação de intervenção do Estado sobre a atividade produtiva.

Tal afirmação merece uma atenção particular, afinal, até o momento, está claro em todas as definições que a política industrial é uma ação de intervenção do Estado sobre a atividade produtiva, porém, em nenhuma delas a idéia de Estado, que se encontra implícita, foi destacada, e isso pode gerar confusões na própria definição de política industrial e nas análises apresentadas nos próximos capítulos.

Para que este problema seja superado, deve ficar claro que o Estado ao qual as definições apresentadas dizem respeito é o Estado Nacional. As definições não se referem aos diversos estados que compõem uma Federação e, conseqüentemente, o 
Estado Nacional; elas se referem ao poder público que possui formas de controle central das atividades do país e detém os instrumentos de política macroeconômica.

Portanto, tendo em mente essa observação, é possível definir política industrial para este trabalho como uma política do Estado Nacional de intervenção sobre os agentes produtivos ligados à nação a partir de diversos instrumentos que se encontram na esfera macroeconômica e microeconômica da sociedade, os quais, na maioria das vezes, também são utilizados por outras políticas do Estado Nacional.

Com isso, deve ficar claro que a política industrial por ser uma política do Estado Nacional, pressupõe uma forma de controle central das ações a serem executadas, que pode ser brando ou altamente intervencionista, dependendo das condições históricas e ideológicas de cada nação.

A política industrial apresenta como objetivo fundamental criar condições para que, a partir da intervenção sobre a atividade dos agentes produtivos, seja possível a conquista de desenvolvimento econômico e bem-estar social em níveis superiores àqueles que seriam possíveis se a política industrial não fosse implementada.

Antes de encerrar esse item, convém destacar que a definição aqui apresentada também se caracteriza pela amplitude. Ela prestigia as definições apresentadas e destaca a questão do Estado Nacional; o que é relevante para a análise posterior.

Ao definir a política industrial como uma política do Estado Nacional, surge uma questão curiosa: se a política industrial é uma política do Estado Nacional, já que pressupõe um controle central, esta definição pode ser ampliada e empregada por 
blocos econômicos ou outras formas de arranjos institucionais entre países ao invés de Estados Nacionais isolados?

A resposta a esta pergunta é sim, desde que essas nações ajam como se fossem um único Estado Nação, sob o ponto de vista da política industrial, ou seja, deve haver uma harmonização de interesses, instrumentos, instituições e uma forma de controle central, para que ocorra uma política industrial que atenda ao interesse geral dos países associados.

Tendo em mente a definição aqui apresentada e as observações feitas, nos próximos itens serão discutidas as diversas visões e instrumentos relacionados à política industrial.

\subsection{Principais Visões}

No desenvolvimento da definição sobre política industrial, foi possível notar que existem controvérsias sobre qual a ênfase a ser dada nesta política e a sua abrangência. Essa situação se justifica porque cada uma das diversas correntes da teoria econômica busca qualificar e analisar o tema a partir do seu próprio referencial teórico. Como os referenciais teóricos das correntes do pensamento econômico apresentam distinções entre si, tais distinções acabam por determinar as posturas destas visões no que se refere ao tema política industrial.

A ação pública realizada pelo Estado Nacional é norteada por concepções teóricas a respeito da realidade, oriundas, no que se refere à política industrial, das diversas escolas do pensamento econômico. Ao longo da história e considerando contextos sociais distintos, diversos foram os casos em que a política industrial foi adotada, às vezes apresentando características próximas a uma visão de mundo, 
ligada a uma determinada teoria econômica, e às vezes apresentando características distintas, vindas de uma outra concepção sobre a Economia.

Ao observar casos históricos vividos por vários países, os teóricos das diversas visões destacam argumentos favoráveis e negativos sobre o emprego da política industrial, os quais são utilizados no debate acadêmico com o objetivo de analisar a validade, os efeitos e a abrangência que deve ser dada à aplicação da política industrial como instrumento de desenvolvimento econômico de uma nação. Além disso, é possível notar que houve momentos na história das diversas nações onde predominaram abordagens amplamente liberais e outros em que as políticas industriais se caracterizaram pelo grande intervencionismo do Estado Nacional sobre a sociedade - o que demonstra que a política industrial adotada na prática varia em função da visão teórica que lhe dá sustentação e do contexto social e histórico no qual ela é adotada.

Ao consultar a bibliografia sobre política industrial foi possível destacar três visões fundamentais, às quais devem ser vistas com extrema atenção para que seja possível compreender a evolução da política industrial adotada no Brasil. Estas visões são a das falhas de mercado, relacionada à teoria econômica neoclássica, da qual a microeconomia tradicional é parte integrante, e as abordagens que dão ênfase ao desenvolvimento e à inovação, associadas às visões tidas como heterodoxas na teoria econômica atual, em particular as visões vindas da escola evolucionista e da abordagem institucionalista, mas também influenciadas por outras visões sobre a Economia, como as teorias sobre o desenvolvimento econômico, por exemplo. 


\subsubsection{Política industrial e falha de mercado}

De acordo com a corrente central da teoria econômica, a neoclássica, ao analisar o tema sob o prisma da microeconomia, é possível destacar que dois fatos podem afastar uma economia de mercado da posição de equilíbrio - situação em que coincidiriam plenamente o interesse privado e o interesse público e na qual a eficiência alocativa da sociedade estaria satisfeita. O primeiro fato se verifica ali onde o mercado apresenta "falhas" que o afastam da condição de concorrência perfeita, o segundo decorreria da própria intervenção dos poderes públicos (CASTRO, 2002, p. 254).

As falhas de mercado podem ser definidas na visão tradicional, segundo PINDIYCK \& RUBINFELD (2002), como situações nas quais os mercados não conseguem por conta própria atingir uma situação de eficiência econômica e o sistema de preços falha em sua função alocativa. Se todos os agentes econômicos, demandantes e ofertantes, fizessem transações em um mercado competitivo, todas as transações realizadas seriam mutuamente vantajosas e a alocação dos recursos resultante seria economicamente eficiente, ou seja, obtida ao menor custo possível. Porém, as falhas existentes nos mercados rẹais impedem que essa situação de eficiência econômica se concretize.

As quatro principais razões para ocorrerem falhas de mercado, capazes de impedir que os mercados se apresentem de modo eficiente sob o ponto de vista econômico são: o poder de mercado existente nas mãos de produtores e/ou consumidores, a assimetria de informação (ou informação incompleta), a presença de externalidades, tanto positivas quanto negativas, e a ausência de certos bens públicos socialmente desejáveis. 
O poder de mercado ocorre quando o ofertante ou o demandante possui a capacidade de afetar a determinação do preço de uma mercadoria qualquer, ele se divide em poder de monopólio e poder de monopsônio.

O poder de monopólio existe quando o ofertante de um determinado bem é capaz de cobrar um preço superior ao custo marginal associado ao bem na venda aos demandantes que compõem o mercado, obtendo assim, lucros extraordinários. Já o poder de monopsônio ocorre quando um demandante, em sua decisão de compra, é capaz de afetar o preço de uma mercadoria oferecida no mercado. Para PINDIYCK \& RUBINFELD (2002), o poder de mercado afeta a eficiência econômica porque, quando empregado, impede que o preço de mercado seja equivalente ao preço de equilíbrio obtido em concorrência perfeita, o que desloca recursos que poderiam ser utilizados em outras finalidades para o consumo do bem no qual o preço não coincide com o preço de equilíbrio ou gera consumo sub-ótimo, sob o ponto de vista da Economia.

O problema da assimetria de informações (ou informação incompleta), acontece sempre que os agentes econômicos não tiverem informações exatas a respeito do preço de mercado ou da qualidade do produto, o que impede que o sistema de preços opere eficientemente. A falta de informação pode provocar a geração de quantidades excessivas de um produto e/ou a produção insuficiente de certos bens, além disso, pode fazer com que o consumidor acabe adquirindo produtos que venham a lhe causar prejuízos e estimula certas posturas oportunistas, às quais podem estar relacionadas tanto ao demandante quanto ao ofertante (PINDIYCK \& RUBINFELD, 2002, p. 597). 
As externalidades, segundo PINDIYCK \& RUBINFELD (2002, p. 597), ocorrem "quando alguma atividade de produção ou de consumo possui um efeito indireto sobre outras atividades de consumo ou de produção, que não se reflete diretamente nos preços de mercado". O autor destaca que o termo externalidade é empregado porque os efeitos mencionados, tanto de custos quanto de benefícios, são externos ao mercado.

Um ponto que deve ser destacado sobre a idéia de externalidade é que elas podem surgir entre produtores, entre consumidores ou entre consumidores e produtores. Além disso, como foi apresentado no parágrafo anterior, há externalidades negativas - que ocorrem quando a ação de uma das partes impõe custos à outra - e externalidades positivas - que surgem quando a ação de uma das partes beneficia a outra.

As falhas de mercado associadas aos bens públicos, acontecem quando o mercado não consegue ofertar esses bens, socialmente valorizados por muitos consumidores. Um bem público é uma mercadoria que pode ser disponibilizada a baixo custo para muitos consumidores, mas, assim que é ofertada para alguns, tornase muito difícil evitar que outros também a consumam. Conforme destaca PINDIYCK \& RUBINFELD (2002, p. 598), o bem público é não exclusivo e não concorrente, o que torna desinteressante aos mercados e às empresas privadas ofertalos à sociedade, fazendo assim, com que a quantidade disponível possa se mostrar insuficiente em relação às necessidades.

Para essa visão, em situações onde fossem identificadas falhas de mercado, é considerada a possibilidade do Estado Nacional agir, no sentido de minimizar essas falhas ou internalizá-las no sistema de preços a partir de ações de comando e controle 
(leis e regulamentações) e/ou incentivos econômicos. Porém, mesmo tendo em mente essa possibilidade teórica, a microeconomia tradicional, ao destacar a função alocativa dos mercados em competição como um de seus principais pressupostos, se coloca descrente com relação ao papel do Estado Nacional sobre a economia, chegando até mesmo a considerar tal ação inviável, mesmo em situações onde fosse possível identificar falhas de mercado.

CASTRO (2002) afirma que para a abordagem neoclássica, ainda quando se conclua sobre a presença de desvios do tipo falhas de mercado, não necessariamente seria recomendada a realização de intervenções corretivas, porque, em primeiro lugar como as falhas de mercado são problemas específicos relacionados aos quatro temas aqui apresentados, as dificuldades técnicas a serem enfrentadas na avaliação, tanto dos desvios, quanto da ação pública necessária à compensação, poderiam fazer com que as políticas adotadas não conseguissem atender a particularidade dos casos observados.

Há também um problema crucial, inerente à própria ação do Estado, que é destacado por CASTRO (2002), ao analisar a microeconomia neoclássica: a gestão do interesse coletivo pelo Estado Nacional não é imune a ineficiências. Assim, por exemplo, podem ocorrer fenômenos conhecidos como "captura" de órgãos públicos por parte de interesses privados e também o favorecimento de medidas de curtoprazo em detrimento de ações de longo-prazo. Além disso, como o Estado democrático é composto por diversos grupos de interesse, podem surgir situações de clientelismo, nepotismo, etc. Numa palavra, é necessário ter em conta possíveis "falhas de governo", segundo CASTRO (2002, p.255). 
Em suma, se os mercados falham em prover o uso eficiente de recursos, existiriam, em tese, espaços para a intervenção pública, na forma de políticas industriais. Assim, segundo uma perspectiva ortodoxa, a política industrial teria finalidade essencialmente corretiva, no sentido de amenizar os impactos negativos das falhas de mercado.

A teoria neoclássica, no entanto, não parece ser uma base apropriada para prescrições de política, conforme destaca CASTRO (2002). Isto porque, devido aos pressupostos de informação e racionalidades perfeitas, típicos da visão ortodoxa, a possibilidade de falhas de mercado é restrita a poucas situações. Porém, se os agentes econômicos falham em assimilar e interpretar quantidades ilimitadas de informação, isto é, se prevalecem a racionalidade limitada e a informação imperfeita, geradora de incertezas, a percep̧̧ão de futuro varia de modo considerável.

Ao serem relaxadas as hipóteses neoclássicas, surgem no campo da teoria econômica oportunidades para que certos agentes tenham vantagens sobre outros ou que alguns possam cometer equívocos. Incertezas, portanto, são geradoras de falhas de mercado e estas podem demandar intervenções públicas, uma impossibilidade dentro do campo conceitual neoclássico (FERRAZ, MENDES \& KUPFER, 2002, p. $552)$.

A rigor, devido às fortes suspeitas, especialmente no que se refere à eficiência alocativa do estado-produtor, a abordagem neoclássica passou, na prática, a recomendar (além de medidas destinadas a melhorar os indicadores macroeconômicos), exclusivamente, políticas voltadas para o aprimoramento da qualidade dos fatores disponíveis (políticas horizontais). Com isto, as versões menos críticas da política industrial (mas que ainda estão filiadas a esta visão) passaram a 
recomendar extrema moderação no seu uso - mesmo diante de comprovadas falhas de mercado, ou seja, a intervenção só seria aceita se e somente se ela fosse justificável quase que de forma inequívoca.

Convém destacar que nos anos 90, em diversos países, foram adotadas posturas com relação à política industrial vinculadas à concepção aqui apresentada. Isto acarretou uma ostensiva ruptura com o passado dessas nações, caracterizado pelo predomínio de um conjunto de políticas industriais totalmente distintas, chamadas de política desenvolvimentista ou "de resultados".

\subsubsection{Política industrial e desenvolvimento}

Para as abordagens que relacionam desenvolvimento e política industrial, um país que ainda não produza um determinado produto pode apresentar maior aptidão à sua produção do que aqueles que já ingressaram na área anteriormente. Muitas vezes, a superioridade inicial de um país sobre os demais se deve apenas ao fato deste ter começado antes. Assim, particularmente nas nações jovens e em crescimento, um sistema de proteção à produção local pode ser defensável, se imposta temporariamente, na esperança de naturalizar aquelas indústrias que guardam uma clara relação com as circunstâncias do país, como, por exemplo, as vantagens comparativas disponíveis (BEDÊ, 1996, p.11).

A condição de que a proteção assuma um caráter temporário decorre da observação de que a superioridade inicial dos países mais desenvolvidos não está relacionada com as economias de escala estáticas, mas sim às economias dinâmicas, que podem ser internas ou externas às firmas. Ou seja, em muitos casos, a superioridade de quem saiu na frente se deve apenas ao processo de aquisição de conhecimento e experiência obtidos no tempo. 
BEDÊ (1996) destaca que, adicionalmente, deve-se levar em conta que a proteção de uma indústria infante envolve elevados custos representados por eventuais subsídios governamentais, pelas perdas iniciais do investidor privado e pelas perdas do consumidor. Portanto, após um tempo, é necessário que a indústria esteja apta não apenas a dispensar a proteção concedida, passando a produzir a preços menores que o preço internacional, como também os benefícios resultantes (incluído aí as externalidades), mais que compensem todos os custos do período de aprendizado, já ajustados por uma taxa de desconto social.

CASTRO (2002, p.257) destaca que são evidentes ao longo da história esforços visando a promoção de autênticos saltos de desenvolvimento industrial, como também a construção ou reconstrução de setores ou regiões. Nos casos clássicos de "emparelhamento" (catching up), o autor destaca que são exemplos a Europa do II pós-guerra, e mesmo os Estados Unidos, frente à brutal pressão exercida pela competição japonesa nos anos 1980. Nestes países, variantes fortes ou fracas de políticas industriais ligadas ao desenvolvimento estiveram presentes.

Para compreender melhor esse tipo de visão sobre a política industrial, devese considerar que a razão fundamental para que diversas soluções superiores não se difundam nos países atrasados é que elas requerem, especialmente nestes contextos, muito mais do que o automatismo do mercado. Estas decisões, conforme destaca CASTRO (2002, p.259) supõem grandes e poderosos atores, exigem uma base diversificada e robusta de serviços (precária ou inexistente nas economias em desenvolvimento), além do compartilhamento de conhecimentos que forem sendo criados com o avanço das novas soluções. 
O mercado, por si, não seria capaz de alavancar mudanças que requerem capacidade de combinar, previamente, decisões mutuamente dependentes. Por esse motivo, a ótica desenvolvimentista guarda estreita relação com o estágio de desenvolvimento das forças produtivas de um determinado país e é tanto mais "intervencionista", quanto mais tardio for o processo de industrialização (FERRAZ, MENDES \& KUPFER, 2002, p. 553).

O Estado-desenvolvimento lidera o mercado, pois as autoridades tomam iniciativas sobre que produtos e tecnologias devem ser encorajados, mobilizando os necessários instrumentos de incentivo e regulação, porém, em geral, subsistem diferenças em termos de taxa de crescimento, estrutura e composição da indústria, instrumentos efetivamente utilizados entre os países que adotam políticas industriais que adotam o desenvolvimento como objetivo. Além disso, a ideologia por trás das políticas empreendidas em cada nação, principalmente quando o processo de industrialização envolve um período longo do tempo, varia de país para país (FERRAZ, MENDES \& KUPFER, 2002, p. 554).

A segunda concepção tem em comum com a primeira o fato de que age (também) através da alteração de preços relativos. Mas ao invés de limitar-se a alterar preços relativos, visando promover a convergência entre ganhos privados e ganhos sociais, seu objetivo é a construção ou recuperação de condições semelhantes às que podem ser encontradas nas economias líderes. Trata-se, pois, concretamente, de replicar no país ou região atrasada a capacidade de produzir existente entre os mais avançados (CASTRO, 2002, p. 260). 


\subsubsection{Política industrial e inovação}

A política industrial ligada ao tema inovação está diretamente relacionada à abordagem evolucionista. Sob a ótica evolucionista deve-se notar que se o primeiro enfoque (das falhas de mercado) admite ambientes concorrenciais como tipos ideais e privilegia categorias universais como o ótimo; se o segundo põe em destaque a intervenção sobre a economia com o objetivo de gerar desenvolvimento a partir da industrialização; com o terceiro ganham relevância as especificidades das empresas.

CASTRO (2002, p.263) destaca que nesta abordagem salta para o primeiro plano o é peculiar à organização, ou seja, suas características essenciais, e é com isto que contam os centros de decisão para, frente à pressão dos competidores, cultivar diferenças, criar e defender posições.

É fácil perceber que, a partir desta perspectiva, tão ou mais importante do que diagnosticar as deficiências e distâncias em relação ao existente nas áreas desenvolvidas ou buscar atingir uma situação de preço de equilíbrio, é mapear aquilo com que se pode contar para continuar avançando. Assim sendo, cabe insistir que a comparação deve contrapor, prioritariamente, a empresa consigo mesma; ou seja, a capacitação, comprovadamente existente, com a que se pode, presumivelmente, alcançar. A categoria básica deixa portanto de ser o atraso (busca de desenvolvimento por emparelhamento) ou uma situação de equilíbrio e passa a ser o potencial criado pelo novo, dado a partir do uso das tecnologias.

Esta busca pela inovação, como postura para a política industrial, visa garantir às unidades produtivas ganhos a partir da inovação e diferenciação, isso ocorre porque estes ganhos são capazes de gerar lucros extraordinários. 
Com o advento da terceira etapa, as políticas industriais de corte tradicional tendem a refluir para uma posição meramente residual. Ao mesmo tempo passam a ter maior relevância as políticas de ciência, tecnologia e de inovação. Aqui, passa a situar-se, indubitavelmente, a nova fronteira das políticas que buscam, diretamente, influenciar a tomada de decisões empresariais - e, por conseqüência, a evolução da economia real. Por que? A resposta está contida no próprio texto. Porque enquanto antes se tratava de construir replicando - ou seja, alinhando-se com o existente em outras partes - agora se trata de explorar o desigual, o localizado, e o até então não percebido (CASTRO, 2002).

Para o país como um todo, e especialmente no campo manufatureiro, esta postura sobre política industrial implica na crescente superação da divisão internacional do trabalho por setores, e o realce progressivo das trocas intra-setoriais (CASTRO, 2002, p. 265), fazendo com que abordagens sobre a cadeia produtiva, sejam vistas com grande interesse.

O Estado tem um papel relevante a desempenhar, seja ampliando a intensidade do processo seletivo, seja criando instituições facilitadoras do processo de geração e difusão de novas tecnologias (FERRAZ, MENDES \& KUPFER, 2002, p. 557). Todavia, não podemos esquecer que os recursos para "fazer política" são limitados, como ficou claro na abordagem neoclássica, e os processos decisórios também são carregados de racionalidade limitada.

Por lidar com a inovação tecnológica, a política industrial pela ótica evolucionista opera, ela própria, sob incerteza, fazendo da existência de uma institucionalidade pública altamente capacitada um importante requisito para o seu sucesso (FERRAZ, MENDES \& KUPFER, 2002, p. 558). 


\subsection{Instrumentos de Política Industrial}

Como já foi destacado por BEDÊ (1996, p.5), as políticas industriais fazem uso de um conjunto muito variado de instrumentos que originalmente se encontram na esfera das demais políticas públicas.

KON (1999) destaca que os instrumentos de ação pública, voltados para a política industrial, podem ser classificados em quatro categorias: fiscais, monetários, cambiais e de intervenção direta, porém, mesmo sendo coerente esta distinção, talvez ela não seja a mais adequada para esse trabalho, já que separa as categorias utilizando terminologias originalmente vinculadas a políticas econômicas específicas - o que pode gerar certa confusão.

Segundo REBELATTO (2003, p.2), “os instrumentos de política industrial procuram criar o entorno necessário para que os empresários e a sociedade possam dar vazão às iniciativas, explorar idéias e desenvolver oportunidades. Além disso, a política industrial deve levar em conta necessidades e características específicas para os diferentes setores".

Sendo assim, ao considerar as questões do "entorno necessário" e das "necessidades e características específicas", a literatura sobre política industrial tem feito a divisão dos diversos instrumentos empregados em dois grandes grupos, ou seja, o grupo dos instrumentos de política industrial horizontal e o grupo dos instrumentos de política industrial vertical.

Para FERRAZ, MENDES \& KUPFER (2002, p.559), "as políticas industriais horizontais são aquelas que buscam melhorar o desempenho da economia na sua totalidade, sem privilegiar alguma indústria específica". Esse tipo de política busca, segundo os autores, alterar o mecanismo geral de alocação de recursos na produção. 
No que se refere às políticas industriais verticais, FERRAZ, MENDES \& KUPFER (2002, p.560) afirmam que estas políticas são as que "privilegiam deliberadamente uma indústria específica" ou seja, a partir de decisões estratégicas, o Estado Nacional mobiliza os instrumentos disponíveis focalizando e privilegiando um conjunto de empresas, indústrias ou cadeias produtivas com o objetivo de modificar as regras de alocação entre os setores ${ }^{5}$.

Além dessa abordagem, os instrumentos de política industrial também podem ser agrupados de acordo com sua natureza. FERRAZ, MENDES \& KUPFER (2002, p.559) citam que os diversos instrumentos de política industrial podem ser vistos como de natureza regulatória ou voltados para incentivos.

Considerando as distinções feitas é possível apresentar os principais instrumentos de política industrial:

\begin{tabular}{|l|l|}
\hline \multicolumn{2}{|c|}{ TABELA 2.1 - PRINCIPAIS INSTRUMENTOS DE POLÍTICA INDUSTRIAL } \\
SEGUNDO A NATUREZA DA POLÍTICA
\end{tabular}

Fonte: elaboração própria a partir de dados obtidos em FERRAZ, MENDES \& KUPFER (2002).

Ao observar esse quadro, talvez ele pareça incompleto. Isso ocorre porque os instrumentos ligados à política macroeconômica e à certas políticas de infra-estrutura

\footnotetext{
${ }^{5}$ Esse tipo de instrumento de política industrial também é conhecido na literatura como políticas seletivas ou de targeting.
} 
não estão presentes. Eles foram suprimidos para que pudessem ser discutidos com atenção particular, para com isso destacar a relação existente entre essas políticas e a política industrial.

Ao observar as políticas macroeconômicas em seu conjunto é possível notar que tais políticas afetam diretamente a política industrial ao criarem possibilidades e limitações ligadas a implementação e efetividade desta forma de ação do Estado Nação.

A política cambial, ao determinar a taxa de câmbio, também determina em grande parte os preços relativos de produtos transacionáveis internacionalmente e de alguns produtos não-transacionáveis. Esta política afetará a política industrial ao estimular ou desestimular investimentos produtivos internacionais. Além disso, a política cambial afetará, por exemplo, os rendimentos das empresas locais que estiverem inseridas de alguma forma no mercado internacional.

Os instrumentos relacionados à política monetária irão afetar o nível e o ritmo de investimento, poupança, crédito e consumo na sociedade - elementos que devem ser vistos como vitais por qualquer tipo de política econômica, devido ao impacto destes sobre a atividade produtiva.

O governo, ao sinalizar com a política fiscal as condições do Estado Nacional de financiar e/ou fomentar políticas industriais verticais ou horizontais, também afeta a política industrial.

Para concluir cabe destacar que a política macroeconômica pode afetar de forma distinta certos setores industriais, mas, quando ela é utilizada com o objetivo de gerar desenvolvimento econômico seus principais instrumentos, monetários e fiscais, tendem a convergir no sentido dos interesses explicitados na política 
industrial. Porém, quando ela visa outros objetivos gerais, seus instrumentos não necessariamente irão caminhar no sentido esperado pela política industrial, o que pode gerar problemas de execução para este tipo de política.

Nas políticas de infra-estrutura se discute a geração de bens públicos ou de um entorno favorável à atividade industrial (o que faz com que tais políticas sejam relacionadas facilmente com política industriais horizontais). Em países carentes de infra-estrutura, ela assume um papel vital, dado o alto volume de inversões às vezes necessárias para sua execução e o baixo interesse do setor privado em certos momentos. Sendo assim, o Estado Nacional, além das suas ações como investidor, deve criar condições para que a iniciativa privada consiga disponibilizar mesmo que parcialmente os recursos necessários à infra-estrutura da sociedade, a um custo economicamente aceitável, as quais, podem ser disponibilizadas a partir da elaboração de marcos regulatórios que sirvam de referência para a tomada de decisão privada.

Para concluir, convém destacar porque em certos casos o Estado Nacional opta por políticas industriais de cunho vertical. As principais justificativas da literatura são que seria vantajoso que certas indústrias fossem incentivadas em comparação a outras caso apresentassem (FERRAZ, MENDES \& KUPFER, 2002):

- Alto valor agregado: o que, supondo tudo o mais constante, poderia gerar aos trabalhadores ali empregados uma maior renda per capita;

- Grande poder de encadeamento: o que poderia gerar um grande efeito multiplicador sobre a cadeia produtiva ligada ao tipo de empresa a ser estimulada, gerando benefícios "para frente" ou "para trás" desta; 
- Indústrias com grande dinamismo potencial: que poderiam ser capazes de gerar um crescimento da renda agregada maior e/ou mais acelerado, que conseqüentemente seria capaz de gerar uma renda per capita maior;

- Indústrias nascentes ou com retornos crescentes de escala: às quais, num primeiro momento tendem a apresentar custos mais elevados do que os apresentados em países que já produzem, mas que em seguida são capazes de anular esse diferencial de custo ou até mesmo produzir a um custo inferior ao apresentado pelos países que iniciaram a produção anteriormente, devido aos retornos crescentes de escala obtidos.

Para concluir este item, convém uma observação: as políticas industriais podem se apresentar de modo explícito ou implícito, dependendo do contexto político da nação. Os países tendem a utilizar com maior intensidade instrumentos verticais ou horizontais caso a concepção sobre a política industrial venha a se aproximar mais ou menos da visão ortodoxa (microeconomia tradicional, das falhas de mercado) ou das visões heterodoxas apresentadas. 


\section{PARTE II - POLÍTICA INDUSTRIAL E REESTRUTURAÇÃO PRODUTIVA}

Agora que os principais elementos conceituais já foram abordados, surge o momento de realizar a argumentação sobre o tema discutido por esse trabalho - a política industrial na reestruturação produtiva da cadeia automotiva brasileira. Esta parte, composta pelos Capítulos III e IV, possui esta finalidade.

O Capítulo III visa destacar aspectos relevantes sobre a cadeia automotiva nacional, ou seja, o capítulo busca colocar em evidência algumas características relacionadas a esta estrutura, sua evolução e alguns aspectos do processo de reestruturação produtiva ocorrido.

No Capítulo IV é discutida como a política industrial afetou a cadeia automotiva nacional ao longo do período estudado. Este capítulo parte dos conceitos e das idéias desenvolvidas na primeira parte do trabalho, toma como referência a caracterização feita sobre a cadeia automotiva no capítulo que lhe antecede e, com base nestes elementos, procura destacar os principais efeitos da política industrial sobre a cadeia automotiva nacional em cada um dos principais momentos vividos após a abertura econômica.

Ao final desta parte são apresentadas as considerações finais ligadas a essa dissertação. Elas foram explicitadas com o objetivo de salientar algumas conclusões obtidas com a pesquisa e indicar questões e temas a serem abordados com maior atenção por trabalhos futuros. 


\section{CAPÍTULO III - A CADEIA AUTOMOTIVA BRASILEIRA}

Nos momentos em que é necessário explicar o que seria um processo produtivo fabril não é raro notar a utilização de ilustrações relacionadas às linhas de montagem de automóveis. As montadoras (peça central da cadeia automotiva) são tidas como um dos principais ícones da indústria.

A utilização das montadoras de automóveis como um dos símbolos da indústria se justifica por uma questão histórica: o surgimento da fábrica fordista no início do século XX. Porém, este símbolo de indústria evoluiu muito ao longo dos últimos anos e é bem provável que a fotografia da montadora obtida nos anos 60 ou 70, já não seja a melhor representação do processo produtivo fabril - atualmente tal processo se organiza de forma muito mais complexa e/ou desverticalizada, se for comparada à forma de organização da produção predominante até o final dos anos 70.

Para ter claro o processo de produção de um automóvel atualmente é cada vez mais importante ter em mente a composição da cadeia automotiva e as interações existentes entre os agentes que a compõem. As montadoras de automóveis continuam apresentando um papel central, porém, a forma como a produção está organizada e estruturada hoje, dentro das montadoras e ao longo da cadeia, apresentou grandes modificações nos últimos anos.

Este capítulo irá apresentar a cadeia automotiva nacional. Ele busca destacar esta estrutura, sua evolução e alguns aspectos do processo de reestruturação produtiva ocorrido que fizeram com que o quadro obtido nos anos 60 ou 70 perdesse parte do seu significado, o que é importante para este trabalho porque torna possível evidenciar ao leitor a grandeza e a complexidade do objeto de estudo aqui abordado. 
Na primeira parte do capítulo será feita uma breve caracterização sobre a cadeia automotiva brasileira. Logo após, no item 3.2, será apresentada a evolução desta cadeia ao longo do período estudado, a partir de dados ligados ao desempenho deste arranjo produtivo. Para concluir, será discutido em linhas gerais o processo de reestruturação produtiva ocorrido na cadeia automotiva brasileira a partir da abertura econômica, no item 3.3. Esse item tem o objetivo de evidenciar e diferenciar os principais momentos desse processo.

\subsection{Características da cadeia automotiva}

De acordo com SARTI (2002, p. 8 e 9), a partir de observações sobre o ambiente internacional, a cadeia automotiva pode ser caracterizada da seguinte maneira:

"O setor automobilístico é um oligopólio global fortemente concentrado, vinte grandes corporações são responsáveis por mais de $95 \%$ de toda a produção mundial. As grandes corporações automobilísticas situam-se entre as maiores empresas industriais do mundo. A capacidade de acumulação de recursos do setor tem extrapolado em muito sua capacidade de crescimento. Como conseqüência as empresas gastam volumosos recursos para dinamizar a demanda através de constantes inovações de produtos, criação de novos nichos de mercado e a exploração de mercados emergentes. Por outro lado, observa-se um intenso processo de racionalização do processo produtivo e inovativo, implicando mudanças organizacionais importantes dentro da cadeia produtiva com fornecedores e revendedores. Simultaneamente tem sido promovidas mudanças patrimoniais decorrentes de decisões de fusão e aquisição (F\&A) de empresas e de estratégias cooperativas nas áreas tecnológicas, produtivas e de comercialização." 
Segundo HUMPHREY \& SCHIMITZ (2000) apud QUADROS \& QUINTÃO (2002), a indústria automotiva é um bom exemplo de uma cadeia dirigida por produtor, as quais se caracterizam por serem cadeias em que empresas transnacionais ou outras grandes empresas integradas desempenham um papel central de controle do sistema de produção em indústrias intensivas em tecnologia e capital.

Enquanto a cadeia consiste em muitas firmas diferentes, as montadoras de automóveis tendem a representar um papel central, controlando o desenvolvimento de produtos junto a seus fornecedores, controlando os padrões de produção, de qualidade do produto e sua distribuição (QUADROS \& QUINTÃO, 2002, p.3).

A cadeia automotiva instalada no Brasil se caracteriza como uma parte integrante do oligopólio global citado por SARTI (2002). Ela é "dirigida pelo produtor", que no caso brasileiro são as filiais das grandes montadoras internacionais, já que são irrelevantes as poucas montadoras nacionais existentes quanto ao controle da cadeia ${ }^{6}$. As decisões tomadas pelas matrizes com relação às subsidiárias instaladas em nosso país determinam o grau de liberdade destas em formular suas estratégias competitivas, além das competências que estarão disponíveis na filial nacional.

$\mathrm{Na}$ cadeia automotiva nacional é possível notar a importante presença das grandes montadoras globais desde sua efetiva implementação, ocorrida nos anos 50 . Também é possível observar que elementos como economias de escala e escopo não

\footnotetext{
${ }^{6}$ Existem poucas montadoras nacionais em atividade, sendo os casos mais relevantes a Troller, fabricante de um tipo específico de comercial leve e a Chamonix, a qual produz réplicas de modelos de carros antigos, como um Porche dos anos 50. As duas atuam em nichos de mercado e devido a seus pequenos volumes de produção não assumem nenhum papel de controle sobre a cadeia automotiva nacional. Durante a história da industrialização brasileira houve tentativas de se desenvolver grandes montadoras nacionais, como, por exemplo, a Gurgel, porém, nenhuma delas conseguiu alcançar sucesso duradouro.
} 
são desprezíveis dentro do processo de produção. A concentração da produção em algumas empresas se explica em certa medida pela existência de barreiras à entrada $\mathrm{e}$ à saída ao longo da cadeia automotiva e também pelo papel distinto que cada montadora atribui à filial em nosso país, entre outros fatores.

No país, existe um setor fornecedor de autopeças bastante heterogêneo, composto por grandes firmas multinacionais e empresas nacionais das mais diversas configurações. O Estado possui uma grande influência sobre as ações e sobre o desempenho da cadeia, sendo que não é difícil notar que ao longo do tempo houve relações tanto de conflito quanto de cooperação entre o Estado e as montadoras. FERRO (1993, p.2), por exemplo, observa que "pela sua relevância econômica, a capacidade do setor gerar desequilíbrios comercias entre nações é muito grande". Sendo assim, os diferentes países desenvolvem diversos tipos de políticas industriais e de comércio exterior específicas para o setor automotivo - o que no caso do Brasil é visto por essa dissertação.

No que se refere à força de trabalho, ela também apresenta uma certa heterogeneidade, pois, enquanto nas regiões tradicionalmente mais industrializadas, como é o caso da região metropolitana do estado de São Paulo, existe uma oferta de mão-de-obra mais qualificada e sindicalizada, em regiões em que a expansão da cadeia automotiva é recente, os níveis de salários e o poder dos sindicatos são distintos daqueles passíveis de observação na região metropolitana de São Paulo.

Outro ponto que caracteriza a cadeia automotiva nacional é a forma como está organizada a comercialização dos veículos novos. Diferente de outros países, como os Estados Unidos, por exemplo, predominam no sistema de distribuição ao consumidor as redes de concessionárias exclusivas, relacionadas a uma marca 
específica de uma montadora. Além disso, o financiamento à comercialização mostra-se como um aspecto fundamental para garantir acesso aos produtos da indústria, dado o baixo nível de renda da população.

No que se refere ao mercado consumidor, é possível notar que as montadoras observam o Brasil como um país estratégico, dada sua posição na América Latina e por existir uma demanda fortemente reprimida, tanto no país quanto na região. Segundo OLIVEIRA (2002, p.11), o mercado nacional se caracteriza por apresentar certa sazonalidade, que em parte está vinculada aos efeitos da safra sobre a economia das regiões agrícolas (principalmente no terceiro trimestre) e em parte ao recebimento do $13^{\circ}$ salário (no final do ano).

Tabela 3.1: Sazonalidade nas vendas (1992-2001)

\begin{tabular}{|c|cccc|}
\hline & $\mathbf{1}^{\mathbf{0}}$ trimestre & $\mathbf{2}^{\mathbf{0}}$ trimestre & $\mathbf{3}^{\mathbf{0}}$ trimestre & $\mathbf{4}^{\circ}$ trimestre \\
\hline Automóveis (montadoras) & 21,8 & 25,2 & 27,9 & 25,1 \\
Comerciais leves (montadoras) & 22,3 & 26,1 & 27,8 & 23,8 \\
Concessionárias na Grande São Paulo & 23,5 & 24,4 & 27 & 25,2 \\
\hline
\end{tabular}

Fonte: OLIVEIRA, 2002, p.08.

Em nosso país há uma baixa densidade de automóveis por habitantes se comparada àquela existente nos principais mercados. Isso faz com que seja considerada a existência de uma demanda reprimida com grande potencial de consumo futuro, porém, por se tratar de um bem durável de alto valor e devido ao perfil da distribuição da renda nacional, bastante concentrada em uma minoria, este potencial depende do desempenho macroeconômico do país para se efetivar. 
Tabela 3.2 - Número de habitantes por automóvel

\begin{tabular}{|c|c|c|c|c|c|c|c|c|c|c|}
\hline PAIS & 1990 & 1991 & 1992 & 1993 & 1994 & 1995 & 1996 & 1997 & 1998 & 1999 \\
\hline Estados Unidos & 1,3 & 1,3 & 1,3 & 1,3 & 1,3 & 1,3 & 1,3 & 1,3 & 1,3 & 1,3 \\
\hline Austrália & 1,7 & 1,7 & 1,8 & 1,7 & 1,7 & 1,7 & 1,7 & 1,7 & 1,6 & 1,5 \\
\hline Itália & 1,9 & 1,9 & 1,8 & 1,8 & 1,8 & 1,7 & 1,7 & 1,7 & 1,7 & 1,6 \\
\hline Canadá & 1,6 & 1,6 & 1,6 & 1,6 & 1,6 & 1,7 & 1,7 & 1,7 & 1,7 & 1,7 \\
\hline Japäo & 2,1 & 2,1 & 2,0 & 2,0 & 1,9 & 1,9 & 1,8 & 1,8 & 1,8 & 1,8 \\
\hline Alemanha & 1,9 & 2,0 & 1,9 & 1,9 & 1,9 & 1,9 & 1,9 & 1,8 & 1,8 & 1,8 \\
\hline França & 2,0 & 2,0 & 2,0 & 2,0 & 1,9 & 1,9 & 1,9 & 1,8 & 1,8 & 1,8 \\
\hline Austria & 2,1 & 2,0 & 2,0 & 2,0 & 1,9 & 2,0 & 1,8 & 1,9 & 1,9 & 1,9 \\
\hline Reino Unido & 2,2 & 2,1 & 2,2 & 2,1 & 2,1 & 2,1 & 2,1 & 2,0 & 1,9 & 1,9 \\
\hline Espanha & 2,7 & 2,6 & 2,5 & 2,4 & 2,4 & 2,3 & 2,2 & 2,1 & 2,0 & 1,9 \\
\hline Bélgica & 2,3 & 2,3 & 2,2 & 2,2 & 2,2 & 2,1 & 2,1 & 2,1 & 2,0 & 2,0 \\
\hline Suécia & 2,1 & 2,2 & 2,2 & 2,3 & 2,2 & 2,2 & 2,2 & 2,2 & 2,1 & 2,1 \\
\hline Rep. Tcheca & 4,5 & 4,4 & 3,9 & 3,4 & 3,6 & 3,0 & 3,2 & 2,6 & 2,5 & 2,7 \\
\hline Coréia do Sul & 13,0 & 10,0 & 8,4 & 7,2 & 6,1 & 5,2 & 4,8 & 4,3 & 4,4 & 4,2 \\
\hline Polônia & 6,1 & 5,1 & 4,9 & 4,9 & 4,9 & 3,8 & 4,3 & 4,3 & 4,3 & 4,3 \\
\hline Argentina & 5,6 & 5,5 & 5,5 & 5,2 & 6,0 & 5,9 & 5,8 & 5,7 & 5,5 & 5,5 \\
\hline México & 8,9 & 8,4 & 8,5 & 7,8 & 7,5 & 7,5 & 7,9 & 7,4 & 7,0 & 6,8 \\
\hline Brasil & 11,1 & 11,1 & 11,1 & 11,1 & 10,4 & 10,3 & 9,4 & 9,1 & 8,8 & 8,8 \\
\hline Federação Russa & 12,0 & 12,0 & 11,0 & 12,6 & 12,6 & 10,7 & 12,0 & 11,2 & 11,1 & 11,1 \\
\hline
\end{tabular}

Fonte: AAMA, Anfavea, SMMT.

Notas:

1. Os dados do Brasil são estimados.

2. Os dados sobre a Alemanha para 1990 se referem à Alemanha Ocidental. A partir de 1991, à Alemanha reunificada

3. Os dados sobre a Federação Russa são a partir de 1991. Em 1990, se referem à URSS

4. Os dados da República Tcheca säo a partir de 1994. Antes se referem à Tchecoslováquia.

A cadeia automotiva nacional pode ser vista como pró-cíclica, ou seja, é sensível à conjuntura nacional e seu desempenho está positivamente correlacionado ao desempenho geral da economia. O mercado interno historicamente sempre foi o mais importante para a cadeia automotiva nacional. Como cita HOLLANDA FILHO (1996), as vendas para o exterior, em geral, costumam assumir um papel complementar, porém, existem sinais de que este quadro está se alterando. No que se refere às exportações, é possível notar que há uma concentração das vendas em certos países demandantes. 


\section{Gráfico 3.1: Países demandantes de automóveis nacionais}
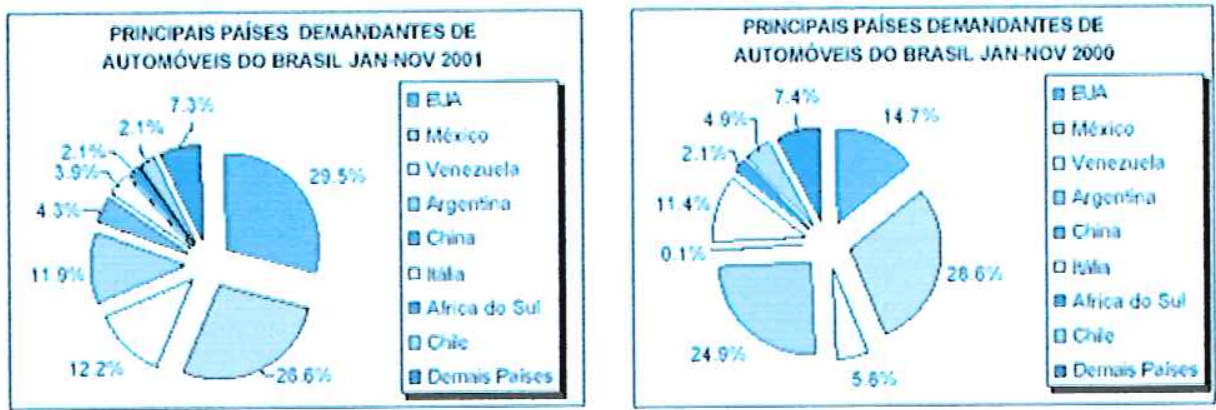

Fonte: OLIVEIRA, 2002, p.7.

Além destes pontos, no que se refere às características da demanda nacional por automóveis e comerciais leves é possível notar que ela encontra-se dividida em três segmentos - frotistas (empresas e governos), pessoas físicas de alto poder aquisitivo e as camadas de renda média. Segundo OLIVEIRA (2002, p.10), os dois primeiros segmentos são relativamente estáveis, de forma que as flutuações de curto prazo ocorrem em função das possibilidades dos consumidores de renda média, condicionados pelo preço dos veículos, condições de financiamento, renda disponível, preço de combustíveis e de carros usados, além de segurança econômica.

Outro ponto a destacar no que se refere à demanda por veículos, é que ela se concentra nos modelos compactos de baixa cilindrada, o que diferencia o nosso mercado de outros. Isso deriva do próprio perfil do consumidor e de incentivos disponibilizados a este tipo de produto pelos governos ao longo do tempo.

Para concluir, deve-se ter claro que algumas características da cadeia automotiva alteraram-se se compararmos sua realidade antes da abertura com a realidade atual. Tais mudanças ficam evidentes a partir dos dados sobre o mercado nacional e ao abordar o processo de reestruturação produtiva ocorrido na cadeia automotiva nacional. 


\subsection{Evolução da cadeia automotiva ao longo do período estudado}

Ao observar alguns dados ligados à cadeia automotiva nacional é possível ter clara a evolução desse arranjo produtivo a partir dos anos 90. Em linhas gerais, notase que o desenvolvimento da cadeia automotiva ocorreu de forma errática ao longo do período estudado, sendo que as variáveis apresentaram fortes momentos de expansão e retração associados ao desempenho macroeconômico do país.

Tabela 3.3 - Produção de Automóveis (1989 - 2003)

\begin{tabular}{|cccc|}
\hline ANO & AUTOMOVEIS & COMERCIAIS LEVES & TOTAL \\
\hline 1989 & 730.992 & 205.008 & 936.000 \\
1990 & 663.084 & 184.754 & 847.838 \\
1991 & 705.303 & 182.609 & 887.912 \\
1992 & 815.959 & 201.591 & 1.017 .550 \\
1993 & 1.100 .278 & 224.387 & 1.324 .665 \\
1994 & 1.248 .773 & 251.044 & 1.499 .817 \\
1995 & 1.297 .467 & 239.399 & 1.536 .866 \\
1996 & 1.458 .576 & 279.697 & 1.738 .273 \\
1997 & 1.677 .858 & 306.545 & 1.984 .403 \\
1998 & 1.254 .016 & 247.044 & 1.501 .060 \\
1999 & 1.109 .509 & 176.994 & 1.286 .503 \\
2000 & 1.361 .721 & 235.161 & 1.596 .882 \\
2001 & 1.501 .586 & 214.936 & 1.716 .522 \\
$2002^{*}$ & 1.521 .431 & 180.030 & 1.701 .461 \\
$2003^{*}$ & 1.506 .333 & 216.535 & 1.722 .868 \\
\hline
\end{tabular}

Fonte: ANFAVEA. 
Gráfico 3.2 - PRODUÇÃO DE AUTOMÓVEIS E COMERCIAIS LEVES 1989-2003

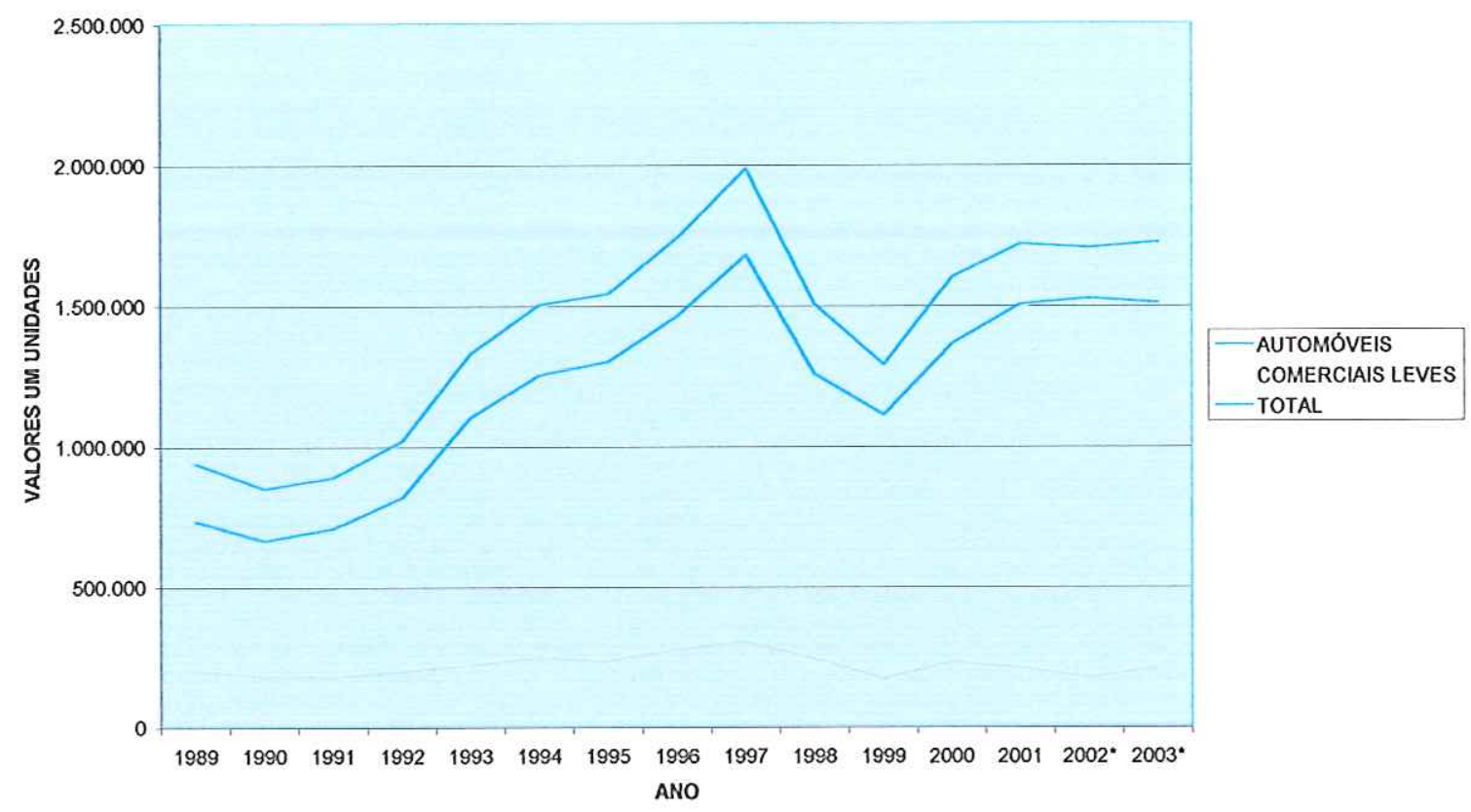

Fonte: ANFAVEA.

No que se refere à produção de automóveis, ela inicia os anos 90 em retração e, a partir de 1991, se expande até atingir o seu recorde histórico em 1997, o qual não é superado até 2003. É possível notar que o comportamento do segmento de comerciais leves acompanha em certa medida o do segmento de automóveis, porém, na maioria dos anos a variabilidade deste segmento é menor, o que é justificado pela característica da demanda citada no item anterior.

Uma característica de processos de reestruturação é o volume elevado de investimentos realizados na implantação de novas unidades fabris ou na reforma e modernização de unidades já estabelecidas.

No que se refere à cadeia automotiva brasileira, mais especificamente às montadoras, é possível notar uma significativa elevação do volume de investimentos entre o período de 1994 e 1998. Essa elevação está associada à entrada de novas 
montadoras no país e também ao aumento do investimento das montadoras já estabelecidas.

Tabela 3.4 - Investimentos realizados na indústria automobilística

\begin{tabular}{|ccc|}
\hline & & milhöes de US\$ \\
\hline ANO & AUTOMOVEIS & TOTAL \\
\hline 1989 & 602 & 602 \\
1990 & 790 & 790 \\
1991 & 880 & 880 \\
1992 & 908 & 908 \\
1993 & 886 & 886 \\
1994 & 1.195 & 1.195 \\
1995 & 1.694 & 1.694 \\
1996 & 2.359 & 2.359 \\
1997 & 2.092 & 2.092 \\
1998 & 2.335 & 2.335 \\
1999 & 1.791 & 1.791 \\
2000 & 1.651 & 1.651 \\
2001 & 1.750 & 1.750 \\
2002 & 976 & 976 \\
\hline
\end{tabular}

Fonte: ANFAVEA - Anuário Estatístico da Indústria Automobilística Brasileira

No caso do setor de autopeças observa-se o peso das montadoras no faturamento e o volume de investimentos realizados, os quais foram estimulados principalmente com o objetivo de modernização para atender às novas demandas das montadoras.

Tabela 3.5 - Faturamento e Investimento da Indústria de Autopeças

\begin{tabular}{|c|c|c|c|c|c|c|c|}
\hline \multirow[b]{3}{*}{ ANO } & \multicolumn{5}{|c|}{ FATURAMENTO } & \multicolumn{2}{|c|}{ INVESTIMENTO } \\
\hline & \multirow[b]{2}{*}{ TOTAL. USS milhöes } & \multicolumn{4}{|c|}{ DISTRIBUICCÁO PERCENTUAL POR DESTINO } & \multirow[b]{2}{*}{ TOTAL USS milhões } & \multirow{2}{*}{$\begin{array}{l}\text { PARTICIPAÇÃO } \\
\text { EM \% SOBRE O } \\
\text { FATURAMENTO }\end{array}$} \\
\hline & & $\begin{array}{c}\text { INDÚSTRIAA } \\
\text { AUTOMOBILISTICA }\end{array}$ & $\begin{array}{l}\text { MERCADO DE } \\
\text { REPOSICAAOO }\end{array}$ & EXPORTAÇÓES & $\begin{array}{c}\text { OUTROS } \\
\text { FABRICANTES }\end{array}$ & & \\
\hline 1989 & 15.544 & 59,7 & 24,8 & 10,2 & 5,3 & 1.061 & 6,8 \\
\hline 1990 & 12.244 & 57,7 & 26,0 & 11,1 & 5,2 & 987 & 8,1 \\
\hline 1991 & 9.848 & 59,5 & 22,3 & 13,5 & 4,7 & 764 & 7,8 \\
\hline 1992 & 10.122 & 60,1 & 20,3 & 15,1 & 4,5 & 715 & 7,1 \\
\hline 1993 & 13.222 & 61,6 & 17,5 & 15,7 & 5,2 & 702 & 5,3 \\
\hline 1994 & 14.376 & 60,4 & 19,3 & 15,5 & 4,8 & 883 & 6,1 \\
\hline 1995 & 16.584 & 59,5 & 19,8 & 15,0 & 5,7 & 1.247 & 7,5 \\
\hline 1996 & 16.122 & 59,5 & 19,5 & 14,6 & 6,4 & 1.296 & 8.0 \\
\hline 1997 & 17.458 & 59,8 & 17,9 & 14,7 & 7,6 & 1.798 & 10,3 \\
\hline 1998 & 14.853 & 58,0 & 19,0 & 17,0 & 6,0 & 1.580 & 10,6 \\
\hline 1999 & 11.213 & 55,2 & 18,6 & 20,7 & 5,5 & 1.020 & 9,1 \\
\hline 2000 & 13.309 & 56.8 & 17.5 & 20,0 & 5.7 & 1.100 & 8.3 \\
\hline 2001 & 11.903 & 57.8 & 17.3 & 18.8 & 6.1 & 798 & 6.7 \\
\hline 2002 & 10.920 & 57.0 & 18.0 & 19.0 & 6.0 & 260 & 2.4 \\
\hline
\end{tabular}

Fonte: SINDIPEÇAS. 
Ao observar os níveis de emprego ao longo do período é possível notar que esta variável apresentava em 2003, um nível bem menor do que aquele registrado no início dos anos 90, o que faz com que seja necessário ponderar os evidentes ganhos de produtividade obtidos ao longo dos anos 90, juntamente com o quadro de retração econômica que abalou o país no período recente.

Tabela 3.6 - Empregos gerados pelo setor de automóveis (1987 - 2003)

Número de Pessoas

\begin{tabular}{|c|c|c|}
\hline ANO & AUTOMOVEIS & TOTAL \\
\hline 1987 & 113.474 & 113.474 \\
1990 & 117.396 & 117.396 \\
1991 & 109.428 & 109.428 \\
1992 & 105.664 & 105.664 \\
1993 & 106.738 & 106.738 \\
1994 & 107.134 & 107.134 \\
1995 & 104.614 & 104.614 \\
1996 & 101.857 & 101.857 \\
1997 & 104.941 & 104.941 \\
1998 & 83.049 & 83.049 \\
1999 & 85.100 & 85.100 \\
2000 & 89.134 & 89.134 \\
2001 & 84.834 & 84.834 \\
2002 & 82.050 & 82.050 \\
2003 & 79.153 & 79.153 \\
\hline
\end{tabular}

Notas: 1. Posição em 31 de Dezembro de cada ano

2. A partir de 1997, esta tabela compreende apenas empregos diretos, excluindo os decorrentes da tercerização de atividades.

No que diz respeito ao desempenho do mercado nacional, dois elementos merecem destaque: a significativa elevação da participação dos carros de baixa cilindrada no total de vendas ao longo do período estudado e a perda de participação dos veículos movidos à álcool ao longo dos anos 90 .

Devido a estímulos do governo, que serão discutidos no próximo capítulo, a participação dos veículos de baixa cilindrada (até 1000 centímetros cúbicos), no total das vendas cresceu de forma intensa ao longo de todo o período estudado, chegando a uma participação recorde de 71,1\% em 2001. 
Tabela 3.7 - Vendas internas de automóveis de 1000cc (nacionais e importados)

\begin{tabular}{|c|c|c|c|}
\hline ANO & AUTOMOVEIS DE 1000 cc & TOTAL DE AUTOMÓVEIS & PARTICIPAÇÃO EM \% \\
\hline 1990 & 23.013 & 532.906 & 4,3 \\
1991 & 67.299 & 597.892 & 11,3 \\
1992 & 92.959 & 596.964 & 15,6 \\
1993 & 243.511 & 903.828 & 26,9 \\
1994 & 450.925 & 1.127 .673 & 40,0 \\
1995 & 602.098 & 1.407 .073 & 42,8 \\
1996 & 703.118 & 1.405 .545 & 50,0 \\
1997 & 880.119 & 1.569 .727 & 56,1 \\
1998 & 748.474 & 1.211 .885 & 61,8 \\
1999 & 625.445 & 1.011 .847 & 61,8 \\
2000 & 777.604 & 1.176 .774 & 66,1 \\
2001 & 920.389 & 1.295 .096 & 71,1 \\
2002 & 820.135 & 1.229 .146 & 66,7 \\
2003 & 707.426 & 1.118 .599 & 63,2 \\
\hline
\end{tabular}

Fonte: ANFAVEA

Quanto ao combustível utilizado, se até os anos 80, devido aos incentivos vindos do PROÁLCOOL, a produção de veículos movidos à álcool chegava a ser equivalente à produção de veículos à gasolina, com o fim dos incentivos esse tipo de combustível quase desaparece das estatísticas, sendo que em 1997, ano do recorde de produção da indústria, eles correspondiam apenas a $0,1 \%$ do total de produção. É possível notar que, a partir de 2001, há uma retomada da participação desse tipo de produto devido ao aumento do preço da gasolina no mercado nacional, em um primeiro momento, porém, a tendência é que veículos que utilizam álcool como combustível venham a retomar participação, graças a uma inovação de produto que tem se difundido com força no país a partir de 2003, os veículos flexíveis em combustível, os quais podem ser abastecidos tanto a álcool quanto à gasolina $\mathrm{e}$ gozam de incentivos fiscais. 
Tabela 3.8 - Produção de veículos por combustível

\begin{tabular}{|r|rrr|rrr|}
\hline \multirow{2}{*}{ ANO } & \multicolumn{3}{|c|}{ AUTOMOVEIS } & \multicolumn{3}{c|}{ COMERCIAIS LEVES } \\
& GASOLINA & \multicolumn{1}{c|}{ ALCOOL } & DIESEL & GASOLINA & ALCOOL & DIESEL \\
\hline 1989 & 383.152 & 345.605 & 2.235 & 72.992 & 52.630 & 79.386 \\
1990 & 590.764 & 71.523 & 797 & 110.788 & 11.736 & 62.230 \\
1991 & 575.755 & 128.857 & 691 & 101.051 & 22.020 & 59.538 \\
1992 & 647.941 & 163.127 & 4.891 & 100.951 & 30.314 & 70.326 \\
1993 & 863.477 & 227.684 & 9.117 & 104.732 & 36.967 & 82.688 \\
1994 & 1.120 .755 & 120.177 & 7.841 & 138.413 & 22.583 & 90.048 \\
1995 & 1.259 .940 & 32.628 & 4.899 & 179.438 & 7.856 & 52.105 \\
1996 & 1.444 .604 & 6.373 & 7.599 & 215.455 & 1.359 & 62.883 \\
1997 & 1.657 .527 & 1.075 & 19.256 & 223.718 & 198 & 82.629 \\
1998 & 1.220 .123 & 1.188 & 32.705 & 168.729 & 263 & 78.052 \\
1999 & 1.068 .791 & 10.197 & 30.521 & 108.144 & 1.117 & 67.733 \\
2000 & 1.315 .885 & 9.428 & 36.408 & 155.165 & 678 & 79.318 \\
2001 & 1.466 .375 & 15.406 & 19.805 & 149.101 & 3.626 & 62.209 \\
2002 & 1.456 .354 & 48.022 & 15.909 & 120.064 & 8.572 & 51.225 \\
2003 & 1.416 .214 & 71.571 & 17.213 & 144.384 & 12.602 & 59.126 \\
\hline
\end{tabular}

Fonte: ANFAVEA

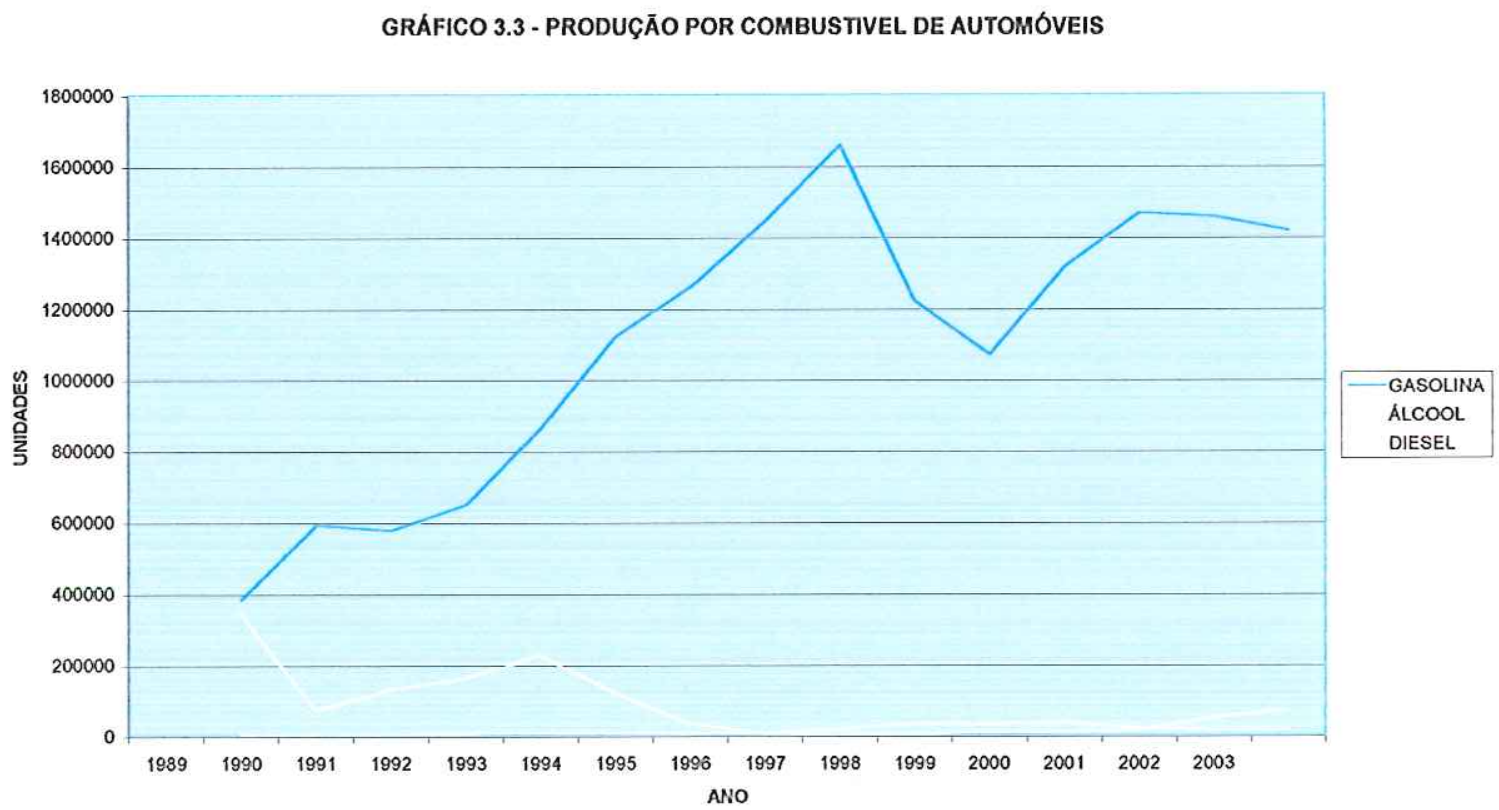

Fonte: ANFAVEA

Para encerrar essas observações convém destacar o desempenho da cadeia automotiva no comércio internacional, já que esta, conforme foi apresentado, possui uma estrutura internacionalizada. No início dos anos 90, era claro que o produto nacional não despertava atratividade nos principais mercados internacionais, além 
disso, no primeiro momento da abertura, foi possível notar que o produto importado apresentava uma boa relação custo-benefício no próprio mercado local.

Tabela 3.9 - Balança Comercial

\begin{tabular}{|c|c|c|c|}
\hline \multirow{2}{*}{ ANO } & \multicolumn{2}{|c|}{ AUTOVEICULOS } & milhões de US\$ \\
\cline { 2 - 4 } & IMPORTAÇĂO & EXPORTAÇÃO & SALDO \\
\hline 1989 & 678 & 2.570 & 1.892 \\
1990 & 733 & 1.897 & 1.164 \\
1991 & 849 & 1.915 & 1.066 \\
1992 & 1.079 & 3.012 & 1.933 \\
1993 & 1.809 & 2.660 & 851 \\
1994 & 2.550 & 2.685 & 135 \\
1995 & 4.795 & 2.415 & -2.380 \\
1996 & 4.882 & 3.013 & -1.869 \\
1997 & 5.105 & 3.929 & -1.176 \\
1998 & 4.692 & 4.264 & -428 \\
1999 & 3.873 & 3.078 & -795 \\
2000 & 3.764 & 3.488 & -276 \\
2001 & 3.717 & 3.614 & -103 \\
2002 & 2.910 & 3.379 & 469 \\
\hline
\end{tabular}

Fontes: Anfavea, Decex (BB), Secex MDIC.

Nota: Esta tabela diz respeito a autoveículos, peças e componentes exportados e importados pelas empresas associadas à Anfavea, exceto Renault e Peugeot Citroën até 1998. 
GRÁFICO 3.4 - BALANÇA COMERCIAL DE AUTOVEICULOS

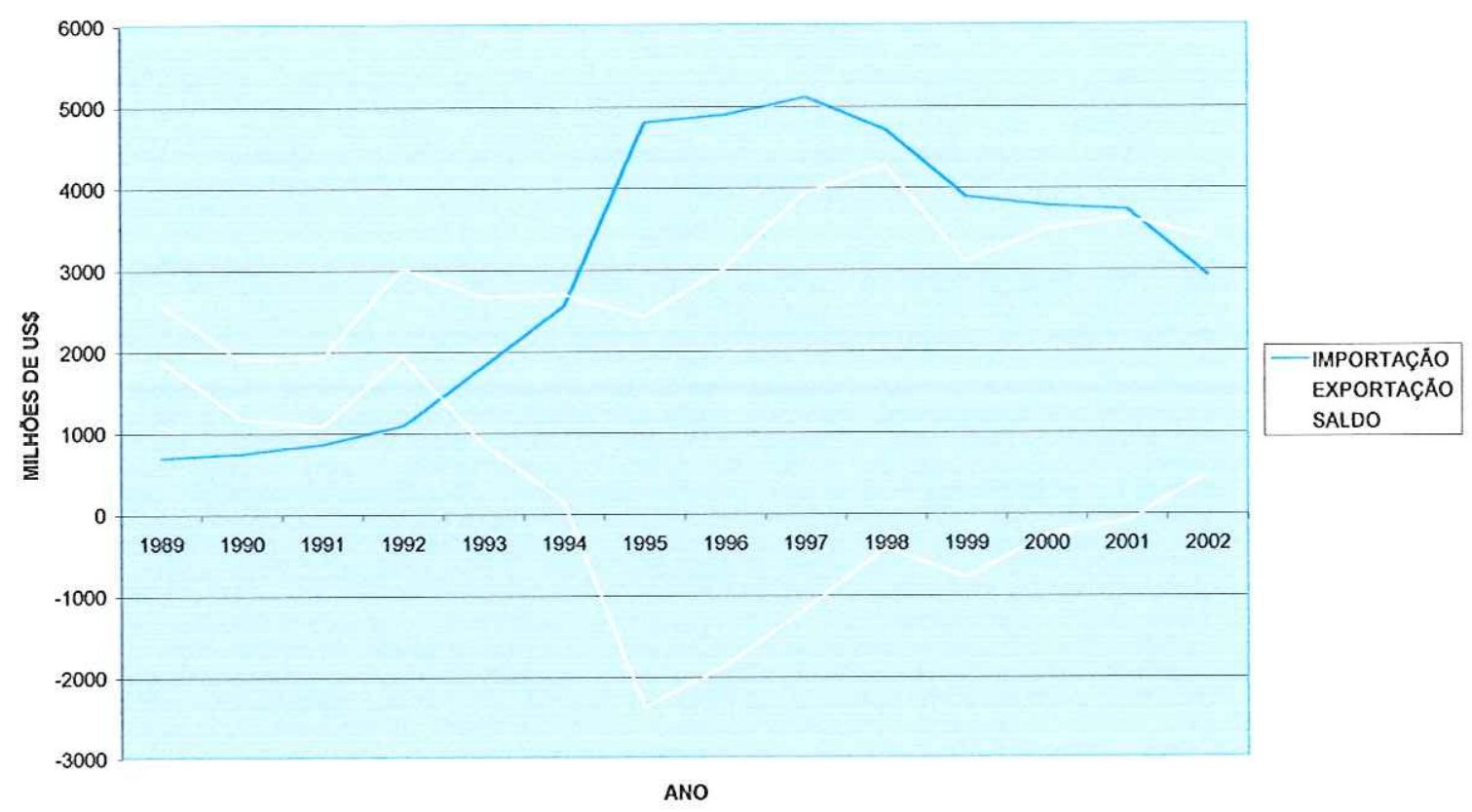

Fonte: ANFAVEA.

Esses dados devem ser vistos com prudência, devido à relação de complementaridade que a cadeia automotiva brasileira possui com os demais países do MERCOSUL, em particular com a Argentina, e também porque certas montadoras que entraram no mercado local no anos 90, tem em seus países ou regiões de origem veículos que são importados para o mercado local com o objetivo de complementar as linhas de veículos disponíveis para o consumidor brasileiro. Isso faz com que sejamos superavitários no confronto com certas regiões e deficitários em outras. 
Tabela 3.10 - Balança comercial Brasil X Países selecionados (automóveis e auto-peças)

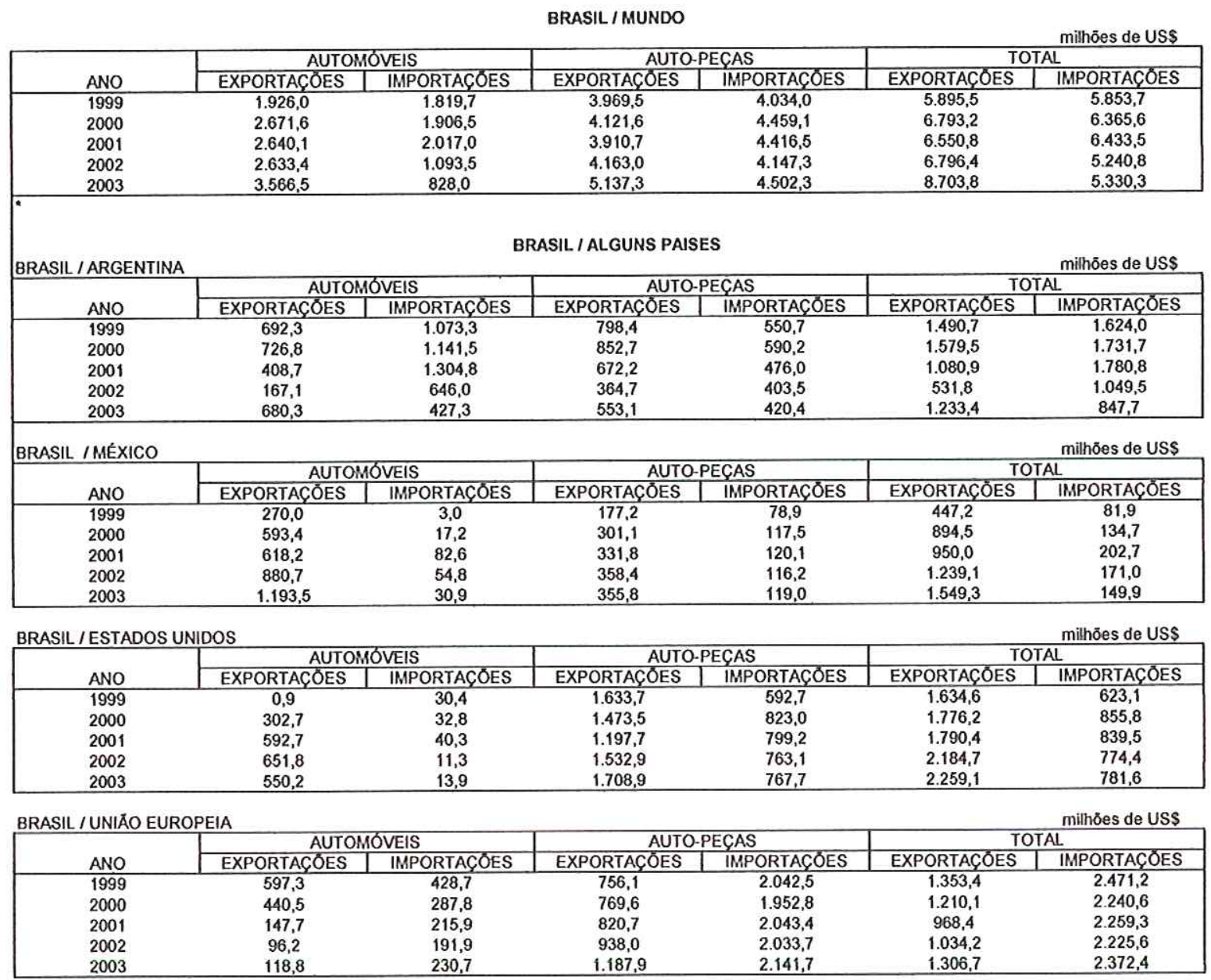

Fonte: ANFAVEA.

\subsection{A reestruturação produtiva na cadeia automotiva nacional}

Com a abertura econômica no início dos anos 90, a cadeia automotiva brasileira realiza uma verdadeira inflexão em sua trajetória, como já foi destacado. Ao observar o processo de reestruturação ocorrido a partir deste momento é possível destacar períodos específicos relacionados à dinâmica desta cadeia produtiva.

HOLLANDA FILHO (1996), consegue realizar uma análise de grande valor sobre a dinâmica da indústria automobilística nacional, entre o período que se inicia 
nos anos 80 e se encerra em meados dos anos 90. Segundo este autor, o processo de reestruturação na cadeia automotiva, que se intensificou na esfera internacional a partir dos 70, com a ascensão da Toyota, passa a ocorrer de maneira efetiva em nosso país somente com a abertura econômica, o que provocou um grande atraso relativo na cadeia automotiva brasileira.

Esta realidade se explica a partir de diversos elementos:

"De um lado, a crise da economia nacional provocou uma retração do mercado interno, que desestimulou a introdução de inovações por parte das montadoras, acomodadas sob um rígido protecionismo. Por outro lado, as perspectivas de expansão das exportações - que alimentavam um otimismo quanto à modernização da indústria local no início da década passada (anos 80) - mostraramse frustrantes, em grande parte como resultado da alteração da forma de reação das grandes montadoras ocidentais à expansão mundial dos japoneses" (HOLLANDA FILHO, 1996, p. 210).

Além disso, as montadoras ocidentais, entre elas as que dominavam o mercado nacional (Volkswagen/Alemanha, Fiat/Itália, General Motors/EUA e Ford/EUA), não souberam acompanhar o ritmo de inovação e competitividade imposto pelas principais montadoras japonesas. Isso obrigou estas empresas a focarem suas ações nos mercados em que sofriam elevada competição, para não perdê-los. Como no Brasil as montadoras instaladas possuíam uma reserva de mercado, dada pelo protecionismo, houve um desestímulo, por parte das matrizes destas montadoras, para a implementação de inovações ao longo dos anos 80 .

Tal situação fez com que a cadeia automotiva brasileira fosse mantida à margem da competição ocorrida na esfera global e também das inovações ocorridas 
na cadeia automotiva internacional (HOLLANDA FILHO, 1996, p. 211). Isso fez com que os anos 80 se caracterizassem como um período de estagnação para a cadeia automotiva nacional.

Enquanto a realidade de estagnação caracterizava a estrutura brasileira, no espaço internacional ocorria o acirramento da competição entre as grandes montadoras, juntamente com a intensificação do desenvolvimento e da difusão de novas tecnologias em diversas áreas da produção, comercialização e distribuição.

No caso brasileiro, a realidade de estagnação e obsolescência só começa a ser modificada com a abertura econômica. A abertura provoca um impacto sobre a cadeia automotiva nacional. $\mathrm{O}$ choque provocado por esta atitude fez com que a cadeia automotiva brasileira saísse da estagnação, dada pelo protecionismo e pelos demais fatores citados, para uma realidade competitiva, porém, essa mudança ocorreu de forma abrupta.

Com a abertura econômica, as montadoras aqui instaladas tiveram a possibilidade de realizar uma nova forma de inserção de suas filiais nas estratégias formuladas pelas matrizes em âmbito global e, portanto, na competição global. Também foi possível a entrada de novos competidores, fornecedores internacionais e o acirramento da disputa pelo mercado interno.

A princípio, a reestruturação da cadeia automotiva brasileira ocorreu de forma reativa, como pode ser notado a partir de vários estudos (FERRO, 1993; ARBIX, 1996; HOLANDA FILHO, 1996 e LAPLANE \& SARTI, 1997).

A reestruturação que vinha ocorrendo na cadeia automotiva internacional tomava como referência um novo modelo de produção, que se originou a partir do caso japonês, o "paradigma tecnológico" havia sido alterado. As empresas instaladas 
no país se viram obrigadas a mudar suas formas de organização da produção desenvolvidas no paradigma anterior (da produção em massa fordista/taylorista), o que inevitavelmente iria trazer um grande impacto para a cadeia automotiva nacional, já que a combinação dos principais fatores produtivos ocorreria de maneira distinta da anterior.

Neste contexto, todos os atores que compõe a cadeia automotiva nacional seriam afetados e, devido a grave situação em que se encontravam, ao invés do conflito eles passam a tomar atitudes cooperativas entre si para tornar possível a reação da cadeia automotiva nacional.

O trabalho de ARBIX (1996), discute em profundidade este momento. Sua pesquisa toma como objeto de análise o importante papel da Câmara Setorial, um fórum de discussão entre os atores ligados à cadeia automotiva nacional. $\mathrm{O}$ autor refaz a trajetória desse arranjo institucional, desde seu nascimento no governo Collor em 1991, até o seu fim, no início do primeiro mandato de Fernando Henrique Cardoso (FHC) (ARBIX, 1996, p.19). Esse arranjo caracteriza o primeiro momento de reação da cadeia automotiva ao processo de abertura econômica do início dos anos 90 , como poderá ser visto posteriormente.

O Plano Real, em 1994, modifica novamente a realidade macroeconômica brasileira e, com isso, provoca um novo choque sobre a dinâmica competitiva da cadeia automotiva nacional. Com o Plano Real, finalmente ocorre a estabilização monetária e conseqüentemente a superação do problema inflacionário. Em seus primeiros anos há um ganho efetivo de poder aquisitivo, a população obtém melhores condições de consumo e junto com essa realidade há o ressurgimento de um sistema 
de financiamento de longo prazo, o que viabiliza a compra de bens duráveis de alto valor, como é o caso dos automóveis.

Esse contexto propicia uma significativa ampliação do mercado consumidor potencial de automóveis em nosso país, o que faz com que as empresas ligadas à cadeia automotiva internacional passem a observar o Brasil como um mercado com grandes possibilidades.

Nesse contexto, a partir de 1994, o Estado, com as novas possibilidades advindas do sucesso do Plano Real, parece alterar sua postura política em relação à cadeia automotiva e passa a atuar de maneira favorável aos interesses das montadoras. Tal situação, discutida por BEDÊ (1997, p.385), possibilitou às montadoras a ampliação de sua liberdade de decisão em relação à cadeia automotiva como um todo (fornecedores, trabalhadores, sindicatos, etc).

Portanto, de um momento reativo ocorrido graças a grave situação de crise em que se encontrava a cadeia automotiva nacional no início dos anos 90, o mercado brasileiro, a partir do Plano Real em 1994, passa a se apresentar como um espaço propício a atitudes pró-ativas por parte das montadoras e dos grandes fornecedores globais, tanto em relação aos seus competidores (estabelecidos ou potenciais) quanto em relação à inserção de inovações tecnológicas (quer sejam de produto ou de processos, incrementais ou radicais).

Entre 1996 e 1997, devido à conjuntura econômica desfavorável com que o país passa a conviver, começa a ficar evidente que os projetos em andamento na cadeia automotiva nacional, principalmente aqueles relacionados às montadoras, poderiam estar superdimensionados com relação ao mercado interno, o que viria a 
provocar um excesso de oferta produtiva. A situação se agravaria em 1999, com a "crise asiática" e a conseqüente mudança no regime cambial.

Nesse contexto, de 1998 até o momento atual, os principais investimentos realizados na construção de unidades produtivas pelas montadoras entrantes iniciam suas atividades. Essas novas plantas produtivas passam a rivalizar diretamente com as unidades produtivas estabelecidas no período anterior a abertura e, desta forma, levam a competitividade na cadeia automotiva ao seu clímax. 


\section{CAPÍTULO IV - POLÍTICA INDUSTRIAL NA REESTRUTURAÇÃO PRODUTIVA DA CADEIA AUTOMOTIVA BRASILEIRA}

Nos anos 90, foi de grande importância o papel da política industrial brasileira sobre a cadeia automotiva nacional. Ela se caracterizou por políticas setoriais, mesmo com o discurso político dos anos 90 destacando os aspectos horizontais das políticas industriais, porém, sua forma de intervenção variou muito e foi muito distinta daquela empregada no período anterior, o que provocou mudanças nas relações entre montadoras e fornecedores, montadoras e governo e entre o governo e os fornecedores de autopeças.

\subsection{A política industrial: da abertura econômica ao surgimento das câmaras setoriais}

Até o fim dos anos 80, o ambiente econômico brasileiro se caracterizava por um elevado protecionismo, alta inflação e defasagem tecnológica, como pode ser visto a partir dos trabalhos de ARBIX (1996), BEDÊ (1997) e KON (1999). Esse contexto demonstrava claramente que havia ocorrido o esgotamento da política industrial adotada até então, que visava, a partir de medidas intervencionistas caracterizadas pelo protecionismo, substituir as importações e criar desenvolvimento a partir do mercado interno.

Nos final dos anos 80 e no início dos 90, as sucessivas reformulações na política governamental visaram principalmente a estabilização a curto-prazo dos preços e, com isso, o controle da inflação, o que fez com que a política industrial implementada pelo Estado Nacional fosse colocada em segundo plano. 
Com os Planos Collor I (março de 1990) e II (janeiro de 1991), houve uma abrupta abertura da economia nacional para o comércio internacional, a política industrial delineada no início do novo governo não se efetivou e, com isso, a tímida política industrial recorreu ao fim dos subsídios governamentais e a uma política de liberalização das importações para estimular a capacidade real de modernização industrial brasileira e atender aos objetivos de elevação da competitividade e da produtividade (KON, 1999, p.201). No entanto, a restrição da atividade econômica, subproduto das medidas de ajuste fiscal e monetário implementadas, juntamente com a carência de recursos, bloqueou o avanço de investimentos consideráveis por parte das empresas privadas e estatais, o que fez com que essa liberalização das importações, um instrumento de política industrial horizontal, viesse a afetar todo o tecido industrial do país, sem necessariamente cumprir com o seu objetivo de gerar modernização.

Como a cadeia automotiva encontrava-se altamente protegida (BEDÊ, 1997), e com elevada defasagem tecnológica se comparada ao contexto internacional, a abertura da economia provocou neste setor um choque, já que tornou claro aos olhos do consumidor as ineficiências da cadeia automotiva nacional.

Devido a esse contexto e agora sem a proteção tarifária no mercado local, a cadeia automotiva se apresentou sem condições de competir com os produtos importados e, assim, passou a apresentar sérios sinais de que poderia ser desarticulada e até mesmo extinta - isso fez com que o governo se visse obrigado a implementar políticas industriais de cunho setorial para essa cadeia, mesmo tendo como discurso a ênfase às políticas horizontais, porém, já não haviam meios para 
essa implementação pois o modelo de intervenção sobre a realidade industrial até então empregado encontrava-se esgotado e, portanto, era inviável.

Nesse contexto, os agentes econômicos que compõem a cadeia automotiva passam a observar a abertura econômica como um elemento de alto risco às atividades locais, principalmente porque a cadeia automotiva se caracteriza como uma das estruturas produtivas mais internacionalizadas.

No primeiro momento relacionado à abertura econômica, o governo passa a sentir que a desarticulação da cadeia automotiva local poderia ocasionar o surgimento e a ampliação de déficits na balança comercial, os trabalhadores começam a temer as demissões, que poderiam ocorrer tanto pelo fechamento de postos de trabalho no país, provocados pela ascensão do produto importado no mercado local, quanto pela modernização da estrutura industrial nacional, que ao tomar como referência as novas formas de organização da produção surgidas na Ásia, Europa e Estados Unidos, iria apresentar como característica a diminuição da necessidade de mão-de-obra na atividade produtiva (o que foi verdadeiro e fica claro a partir dos dados sobre emprego).

As montadoras locais, por sua vez, não tinham claro o papel que iriam desempenhar nas estratégias competitivas da matriz nesse novo contexto de mercado e seus produtos não possuíam o nível de qualidade exigido para as exportações ou mesmo para rivalizar com produtos importados em certos segmentos. No caso dos fornecedores de autopeças locais, havia um grande temor com relação à desnacionalização da indústria de fornecimento e à perda de relevância na cadeia de valor da indústria, que poderia ser provocada por práticas de compras de componentes importados pelas montadoras, como por exemplo o global sourcing. 
Tendo em mente esses temores, é possível destacar que o momento da abertura econômica criou um contexto no qual todos os agentes que compõem a cadeia se encontravam em uma situação desfavorável se comparado ao contexto internacional ou às suas necessidades.

É nesse contexto que surge o arranjo institucional analisado por ARBIX (1996), na sociedade brasileira e em particular no âmbito da cadeia automotiva brasileira - a câmara setorial da indústria automobilística, criada em dezembro de 1991 - uma nova dinâmica de relacionamento entre Estado, sindicatos de trabalhadores e entidades da indústria automobilística brasileira que constituíram de forma consensual um espaço de negociação tripartite (ARBIX, 1996, p. 18).

\subsubsection{A atuação das câmaras setoriais}

ARBIX (1996) destaca que a câmara setorial se mostrou como um dos principais elementos no que diz respeito à superação da situação de crise explicitada na cadeia automotiva com a abertura econômica e que o seu surgimento só foi possível graças a um contexto muito particular, ocorrido no início dos anos 90, no qual "I - o governo não contava com capacidade para assumir plenamente seu papel dirigente na sociedade, em uma situação em que o livre jogo do mercado acentuava ainda mais a crise da indústria; II - os diversos segmentos do setor industrial demonstravam capacidade de organização, de articulação e de representação dos seus interesses" (ARBIX, 1996, p.60).

As câmaras setoriais se tornaram um instrumento de política industrial que, além de dispor de incentivos fiscais do governo, foram um novo arranjo institucional que tornou possível o desenvolvimento de acordos e compromissos, os quais agiram 
de forma reativa ao contexto de crise na cadeia automotiva e possibilitaram a sobrevivência da cadeia automotiva aqui instalada.

Os dados da cadeia automotiva entre 1991 e 1994, evidenciam a força desse arranjo institucional no sentido de evitar a desarticulação da cadeia automotiva.

\subsubsection{4: Novos rumos para a política industrial}

Se em um primeiro momento, com as Câmaras Setoriais, a política industrial na cadeia automotiva brasileira apresentava a cooperação entre os agentes como uma característica, já a partir de 1994, com a mudança do governo, essa característica se desfaz e o Estado Nacional passa a ser o tomador de decisão no que se refere aos rumos da política industrial.

A política industrial para a cadeia automotiva, passa, a partir de então, a dar ênfase às relações entre a cadeia automotiva aqui instalada, o MERCOSUL, e o mercado internacional, mas realiza muito pouco no sentido de estimular o mercado interno, já que este estímulo era tido como certo, caso as políticas macroeconômicas obtivessem êxito.

\subsubsection{Os investimentos na Cadeia Automotiva}

Foram realizados vultosos investimentos por parte das montadoras e de alguns fornecedores na cadeia automotiva nacional, os quais tomaram como referência o potencial aparente da economia brasileira, principalmente em meados dos anos 90. O Estado Nacional disponibilizou incentivos fiscais a essas organizações, mas, devido ao deslocamento destes incentivos do âmbito federal para o âmbito local, ocorreu um elevado ônus fiscal para o Estado, devido à disputa entre os diversos estados da federação pelos investimentos na cadeia automotiva, o que 
possibilitou a apropriação de benefícios públicos pelo setor privado, em particular pelas montadoras.

Nos momentos em que a demanda se mostrou reprimida, devido aos choques externos, a política industrial utilizou cortes e reduções tributárias, visando reaquecer a demanda até que a conjuntura melhorasse, porém, tais cortes em certos casos não foram repassados na sua totalidade para os consumidores.

Nesse ponto seria interessante uma discussão sobre o impacto daquilo que se convencionou chamar de Guerra Fiscal no que diz respeito à cadeia automotiva. Uma das principais justificativas a respeito dos incentivos fiscais para a instalação de montadoras em certas regiões do país consistia na capacidade hipotética dessas de gerar empregos (diretos e indiretos). Se forem vistos os dados sobre empregos diretos gerados pela cadeia automotiva, em particular pelas montadoras, é possível afirmar que não foram gerados em grandes volumes novos postos de trabalho. Nesse ponto, seria interessante a realização de uma análise no sentido de mensurar até que ponto os benefícios públicos disponibilizados às montadoras como apoio a suas decisões de investimento foram apropriados ou não na forma de benefícios privados pelas montadoras.

\subsubsection{Crises econômicas e competição em mercado estagnado}

No sentido de elevar as barreiras à entrada e proteger-se das montadoras entrantes, as montadoras estabelecidas ampliaram suas capacidades produtivas a partir de 1994. Esta atitude parecia indicar que as montadoras estabelecidas estariam dispostas a ocupar o espaço e a escala possibilitada pela ampliação do mercado brasileiro, antes que as empresas entrantes a ocupassem. A Volkswagen, por 
exemplo, cria novas unidades produtivas no Paraná, mesmo antes de modernizar sua fábrica no $\mathrm{ABC}$.

Entre 1997 e 1998, devido à conjuntura econômica desfavorável que já começa a ser notada, fica evidente que os projetos em andamento na cadeia automotiva nacional, principalmente aqueles em desenvolvimento pelas montadoras, poderiam estar superdimensionados com relação ao mercado interno, o que poderia provocar um excesso de oferta produtiva. A situação se agravaria em 1999, com a "crise asiática" e a conseqüente desvalorização do Real, que impõe às empresas com maior dependência de componentes importados um encarecimento em seus custos.

Nesse contexto, de 1998 até 2002, os principais investimentos realizados na construção de unidades produtivas pelas montadoras entrantes iniciam suas atividades. Essas novas plantas produtivas passam a rivalizar diretamente com as montadoras estabelecidas e levam a competitividade na cadeia automotiva ao seu clímax. O problema é que essa situação de intensificação na competição e elevada disputa entre as montadoras passa a ocorrer em nosso país dentro de uma realidade muito distinta daquela prevista em 1994: uma realidade na qual o mercado nacional encontrava-se reprimido e com uma situação cambial instável.

Hoje é possível notar que mesmo com implicações negativas como a desnacionalização do setor fornecedor de autopeças, as diversas transformações ocorridas na cadeia automotiva nacional possibilitaram o surgimento de um ambiente competitivo e dinâmico:

"Foi-se o tempo em que a indústria automobilística olhava de lado para o Brasil. Se os projetos do setor eram vagarosos e tímidos ao longo dos anos 70 e 80 , quando apenas quatro grandes marcas produziam carros no país, hoje eles só 
sugerem ambição. De mercado sem opções, preços altos e sem crédito, conhecido pelos produtos antiquados, o Brasil virou um fenômeno automobilístico mundial" (VILADARGA, GAZETA MERCANTIL, 04/08/2000, p. C1).

O Brasil, mesmo com sua situação conjuntural desfavorável, é visto atualmente como uma área de grande importância estratégica para as filiais das montadoras, das fornecedoras de autopeças globais e por suas matrizes. Além disso, o mercado brasileiro, ampliado pelo MERCOSUL, parece ser visto como uma “arena" privilegiada na qual possivelmente serão definidos alguns dos líderes e perdedores no âmbito da cadeia automotiva internacional, devido a incapacidade dos mercados maduros de absorver a produção no ritmo que a indústria automobilística internacional deseja.

Nesse contexto, é interessante notar como as empresas que se estabeleceram antes da abertura têm reagido à competitividade imposta atualmente pelas montadoras entrantes. Na verdade, são as montadoras que já estavam estabelecidas as que mais tem investido na disputa pelo mercado interno, a partir da inserção de novos produtos e do desenvolvimento de projetos voltados para as especificidades locais. Nesse contexto, políticas industriais que fossem capazes de estimular a inovação e o desenvolvimento de novos produtos poderiam se bem vindas.

\subsection{3: O primeiro ano de um novo governo}

No primeiro ano do governo Lula, não foi possível notar nenhuma modificação no padrão de política industrial, como a demanda encontrava-se reprimida, recorreu-se novamente a uma renúncia fiscal do governo, no sentido de estimular novamente as vendas. O que é possível notar de diferente no contexto do novo governo é que as exportações da cadeia automotiva passam a crescer em um 
ritmo vigoroso, o que se justifica graças ao câmbio favorável e a um maior esforço exportador das montadoras aqui instaladas que passam a oferecer o produto nacional, caracterizado por carros compactos, a países com características de demanda semelhantes a do Brasil. 


\section{CONSIDERAÇÕES FINAIS}

As políticas industriais implementadas sobre a cadeia automotiva nacional ao longo dos anos 90, se caracterizaram pelo seu aspecto setorial, porém, a forma de atuação sobre a atividade produtiva variou bastante durante o período estudado.

Em um primeiro momento a política adotada se caracterizou como reativa, e contou com o apoio de todos os agentes que compõem a cadeia automotiva, naquela estrutura conhecida como Câmara Setorial. A partir do Plano Real, com a estabilidade econômica, esse arranjo reativo não se sustentou e o Estado Nacional volta a ser o centro das decisões relacionadas à cadeia automotiva. Alguns autores destacam que nesse momento o Estado passa a privilegiar os investimentos feitos pelas montadoras, em detrimento das empresas do ramo de autopeças.

Nesse contexto, diferente de outros momentos, o Estado Nacional já não possuía o controle pleno dos instrumentos fiscais que poderiam ser direcionados para a efetivação da política industrial. Sendo assim, os municípios e estados, aproveitaram da posse de tais instrumentos e passaram a gerar diversas disputas por investimentos produtivos, conhecidas como Guerras Fiscais, as quais podem ter ocasionado uma elevada perda de renda pública a favor de interesses privados, a qual ainda merece necessita de uma mensuração, que não foi objetivo desse trabalho.

Ao longo dos momentos de crises conjunturais, após o Plano Real, o Estado Nacional agiu a partir de isenções fiscais, as quais nem sempre foram repassadas plenamente ao preço pago pelos consumidores.

Com a mudança de governo em 2003, não foi percebida, pelo menos no primeiro ano de mandato, uma mudança nas características da Política Industrial adotada pelo Estado Nacional, as isenções fiscais continuaram sendo utilizadas. 
Dentro do período estudado certas medidas empregadas mudaram a característica da demanda por veículos em nosso país. O decreto do carro popular, modificou a característica da demanda interna, fazendo com que essa se caracterizasse com a forte presença dos veículos de baixa cilindrada. O fim do PRÓALCOOL, fez com que os carros movidos a esse combustível perdessem participação no mercado e os incentivos fiscais ligados aos carros flexíveis, juntamente com os benefícios vistos pelo próprio consumidor, fizeram tem feito o perfil da demanda nacional mudar novamente e tem estimulado às montadoras que encontram-se aqui estabelecidas criarem versões que atendam a essa particularidade.

As políticas industriais para a cadeia automotiva, sob o ponto de vista do consumidor nacional, não discutiram em profundidade as condições deste. Pouco foi feito, por exemplo, no que se refere ao desenvolvimento das formas de comercialização e financiamento para esses consumidores. Havia claro por parte do Estado, principalmente a partir do Plano Real, que a estabilidade econômica por si só iria trazer o desenvolvimento do mercado interno.

Portanto, a política industrial adotada não manteve um padrão claro ao longo dos anos 90, ao mesmo tempo em que foi eficaz ao garantir a sobrevivência e o desenvolvimento da indústria local, não conseguiu reagir de forma adequada às situações de crise no mercado interno. 


\section{BIBLIOGRAFIA}

ANUÁRIO ESTATÍSTICO DA INDÚSTRIA AUTOMOBILÍSTICA BRASILEIRA (2003) (2002) (2001) (2000). Associação Nacional dos Fabricantes de Veículos Automotores - ANFAVEA.

ARBIX, G. \& ZILBOVICIUS, M. (org.) (1997). De JK a FHC: a reinvenção dos carros. São Paulo, Editora Scritta.

ARBIX, G. (1996). Uma aposta no futuro: os primeiros anos da câmara automobilística. São Paulo, Editora Scritta.

ARBIX, G. (1997). A câmara banida em ARBIX, G. \& ZILBOVICIUS, M. (org.) (1997). De JK a FHC: a reinvenção dos carros. São Paulo, Editora Scritta.

AZEVEDO, P. F. (1995). Integração vertical e barganha. São Paulo, Tese, FEA/USP.

BEDÊ, M. A. (1996) A indústria automobilística no Brasil nos anos 90: proteção efetiva, reestruturação e política industrial. Tese apresentada à Faculdade de Economia, Administração e Contabilidade da Universidade de São Paulo, São Paulo.

BEDÊ, M. A. (1997). A política automotiva nos anos 90, in ARBIX, G. \& ZILBOVICIUS, M. (org.) De JK a FHC: a reinvenção dos carros, São Paulo, Editora Scritta.

BOTOMÉ, S.P. (1997). Processos comportamentais básicos em metodologia de pesquisa: da delimitação do problema à coleta de dados. Caxias do Sul, Chronos, v.30, n.1, p.43-69, jan/jun.

CALDAS, S. (2002) Lula herda proposta de política industrial. O Estado de São Paulo, 8 de dezembro, p. B1; B3.

CARTAS DA ANFAVEA (2004) (2003). Associação Nacional dos Fabricantes de Veículos Automotores - ANFAVEA.

CASTRO, A. B. (2002) A rica fauna da política industrial e a sua nova fronteira. Revista Brasileira de Inovação, vol. 1, número 2, julho/dezembro.

CERVO, A. L.; BERVIAN, P. A. (1983). Metodologia científica: para uso dos estudantes universitários. $3^{\text {a }}$ ed, São Paulo, McGraw Hill do Brasil.

CHESNAIS, F. (1996). A mundialização do capital. São Paulo, Editora Xamã.

COASE, R. (1937). The nature of the firm, Economica.

CONSONI, F. (2003) Relatório de pesquisa FINEP, setor: autoveículos montadoras. Departamento de Política Científica e Tecnológica, Instituto de Geociências, Universidade Estadual de Campinas, Campinas, São Paulo.

COUTINHO, L. \& FERRAZ, J. C. (coord.) (1995). Estudo da competitividade da indústria brasileira, $3^{\mathrm{a}}$ ed., Campinas, Papirus Editora/Editora da Universidade Estadual de Campinas.

DANTAS et. al. (2002) Empresa, indústria e mercado in KUPFER, D. \& HASENCLEVER, L. (org.) (2002). Economia industrial, São Paulo, Editora Campus.

DOSI, G. (1984). Technical change and industrial transformation: the theory and application to the semiconductor industry, Londres, Macmillan.

DOSI, G. (1988). Technical change and economic theory. London; New York, Pinter Publishers.

FERGUSON, C. E. (1976). Teoria Microeconômica. São Paulo, Editora Forense Universitária. 
FERRAZ et al. (2002). Política industrial in KUPFER, D. \& HASENCLEVER, L. (org.) (2002). Economia industrial, São Paulo, Editora Campus.

FERREIRA, A. B. H; FERREIRA, M. B. ANJOS, M. (1999). Novo Aurélio Século XXI. Rio de Janeiro, Editora Nova Fronteira.

FERRO, J. R. (1993). Competitividade da indústria automobilística. Nota técnica setorial do complexo metal-mecânico in Estudo da competitividade da indústria brasileira, Campinas, MCT; FINEP; PADCT.

FONTENELE, A. M. C. (1995). Progresso e método na história das teorias de organização industrial. São Paulo, Tese, FEA/USP.

FREEMAN, C. (ed.). (1990). The economics of inovation.

FURTADO, J. E. M. P. (2001) Meia política industrial? Folha de São Paulo, 8 de janeiro, p. B2.

GREMAUD et. al. (2003) Economia brasileira contemporânea. $4^{\mathrm{a}}$ ed. São Paulo, Editora Atlas.

HALL, R \& HITCH, (1939). Price theory and business behavior. Oxford Economic Papers, n.2, p. 12-45.

HAY, D. (1998) Industrial policy in Brazil: a framework. Texto para discussão ${ }^{\circ}$ 551, IPEA, Rio de Janeiro, março de 1998.

HOLLANDA FILHO, S. B. (1996). Os desafios da indústria automobilística. A crise da modernização. São Paulo, IPE/USP.

KON, A. (1999) Economia Industrial, São Paulo, Editora Atlas.

KRUGMAN, P. (1989). Industrial organization and international trade, in SCHMALENSEE, R. \& WILLIG, R. D. (orgs.) Handbook of industrial organization, vol. 2, North Holland, Amsterdam.

LABINI, P. S. (1982). Oligopólio e progresso técnico. Rio de Janeiro, Editora Forense Universitária.

LAPLANE, M. F. \& SARTI, F. (1995). A reestruturação no setor automobilístico brasileiro nos anos 90. Economia de Empresas, São Paulo, v.2, n.4, p.32/59, out./dez.

LAPLANE, M. F. \& SARTI, F. (1997). The Restructuring of the Brazilian automobile Industries in the Nineties. Actes du GERPISA, n²0, pp 31-48, maio.

LEMOS, M. B; DINIZ, C. C; SANTOS, F. B. T; AFONSO, M. A. C; CAMARGO, O. (CEDEPLAR/UFMG). (2000). O arranjo produtivo da rede FIAT de fornecedores. Nota Técnica 15, Estudos Empíricos, Projeto de Pesquisa Arranjos e Sistemas Produtivos Locais e Novas Políticas de Desenvolvimento Industrial e Tecnológico, Rio de Janeiro, IE/UFRJ, julho.

MARX, R. (1995) A indústria automobilística brasileira in CASTRO, N. A. A máquina e o equilibrista. São Paulo, Editora Paz e Terra, 1995.

METCALFE, J. S. (1988). The diffusion of innovation: an interpretative survey, in DOSI, G. et al. (org.). Technical change and economic theory. Londres, Printers Publishers.

NELSON, R. \& WINTER, S. (1982). Evolutionary theory of economics change. Massachusetts, Cambridge.

OICA (2002). International organization of motor vehicle manufacturers. Dados estatíticos, http://www.oica.net/htdocs/statistics/statistics.htm - consultada entre dezembro de 2001 e janeiro de 2002.

OLIVEIRA, A. F. (2002). Brasil - Autopeças e veículos: veículos leves. Análise setorial realizada pela consultoria LAFIS em fevereiro. 
PINHO, D. B. \& VASCONCELLOS, M. A. S. (org.) (1998). Manual de Economia. São Paulo, Editora Saraiva, $3^{\mathrm{a}}$ edição.

PORTER, M. E. (1986) Estratégia competitiva: técnicas para análises de indústria e da concorrência. Rio de Janeiro, Editora Campus.

POSSAS, M. L. (1980). Oligopólio e progresso técnico. São Paulo, Editora Forense Universitária.

POSSAS, M. L. (1985). Estruturas de mercado em oligopólio. São Paulo, Editora Hucitec.

POSTHUMA, A. C. (1993). Competitividade da indústria de autopeças. Nota técnica setorial do complexo metal-mecânico. in Estudo da competitividade da indústria brasileira, Campinas, MCT; FINEP; PADCT.

QUADROS, R. \& QUINTÃO, R. (2002). Globalização, coordenação econômica e desenvolvimento tecnológico na cadeia automotiva brasileira. Texto apresentado no III Seminário de Economia Industrial - Política Industrial e Desenvolvimento Econômico, do Grupo de Estudos em Economia Industrial, GEEIN/UNESP, Araraquara, 14 a 16 de agosto.

RABELO, F. M. (1996). Proposta de metodologia para análise de grupos econômicos. in Revista de Administração de Empresas, São Paulo, vol. 36, nº 02, p. 26/33, abr./mai./jun.

ROSEMBURG, C. (2000). Um salto no tempo: como Herbert Demel está transformando as duas Volkswagens existentes no Brasil. Revista Exame, p. 88 a 92, 13 de dezembro.

SALERNO, M. S. (1997). A industria automobilística na virada do século em ARBIX, G. \& ZILBOVICIUS, M. (org.) (1997). De JK a FHC: a reinvenção dos carros. São Paulo, Editora Scritta.

SALERNO, M. S; MARX, R; ZILBOVICIUS, M; GRAZIANO, T; DIAS, A. V. C; MUNIZ, S. T. G; GARCIA, R. C; LIMA, J. C. S; IVESON, S; HOTTA, M. A; SOARES, R. (2002). A nova configuração da cadeia automotiva brasileira. Pesquisa desenvolvida junto ao BNDES, www.poli.usp.br/pro/cadeiaautomotiva, São Paulo, Escola Politécnica da Universidade de São Paulo, Departamento de Engenharia de Produção, novembro.

SALERNO, M. S; ZILBOVICIUS, M; ARBIX, G; DIAS, A. V. C. (1998) Mudanças e persistência no padrão de relações entre montadoras de autopeças no Brasil: proximidade, global e follow sourcing, parcerias e co-design revisitados. Relatório de pesquisa no âmbito de projeto sobre relação entre montadoras e fornecedores coordenado pelo Instituit Arbeit und Technik, Gelsenkirchen, Alemanha. São Paulo, fevereiro.

SANDRONI, P. (1999). Novíssimo dicionário de Economia. São Paulo, Editora Best Seller.

SARTI, F. (2002). Cadeia automobilística. Nota técnica final do estudo da competitividade de cadeias integradas no Brasil: Impactos das zonas de livre comércio. Campinas, dezembro.

SCHERER, F. M. \& ROSS, D. (1990). Industrial market structure and economic performance, $3^{\text {a }}$ edição, Boston Houghton Mifflin.

SCHUMPETER, J. H. (1912) (1997). Teoria do Desenvolvimento Econômico. São Paulo, Editora Nova Cultural. 
SCHUMPETER, J. H. (1939). Business cicles: a theoretical, historical and statistical analysis of the capitalist process. $1^{\text {st }}$ ed. New York, London, McGrawHill Book Company.

SCHUMPETER, J. H. (1942) (1983). Capitalismo, Socialismo e Democracia. Rio de Janeiro, Zahar Editora.

SIFFERT FILHO, N. F. (1995). A economia dos custos de transação. in Revista do BNDES, $\mathrm{n}^{\circ}$ 04, dezembro.

SILVA, C. (2001). Montadoras veteranas modernizam-se para enfrentar as novatas. Jornal O Estado de São Paulo, 26 de fevereiro.

SILVA, E.L.; MENEZES, E.M. (2001). Metodologia da pesquisa e elaboração de dissertação. Programa de Pós-graduação em Engenharia de Produção, Laboratório de Ensino a Distância. Universidade Federal de Santa Catarina, Florianópolis.

SLACK, N; CHAMBERS, S; HARLAND, C; HARRISON, A; JOHNSTON, R. (1997). Administração da Produção. São Paulo, Editora Atlas.

SUZIGAN, W. (1998). Política e desenvolvimento industrial. Grupo de Trabalho desenvolvido no XXIV Encontro Nacional dos Estudantes de Economia ENECO, UNICAMP, Campinas.

TRIVIÑOS, A.N.S. (1987). Introdução à pesquisa em ciências sociais: a pesquisa qualitativa em educação. São Paulo, Atlas.

UNIVERSIDADE DE SÃO PAULO. Escola de Engenharia de São Carlos. Serviço de Biblioteca. (1996). Diretrizes para elaboração de dissertações e teses na EESC - USP. São Carlos.

VARIAN, H. R. (1999). Microeconomia: princípios básicos. Rio de Janeiro, Editora Campus.

VASCONCELLOS (2002). Economia: micro e macro. São Paulo, Editora Atlas

VILADARGA, V. (2000). Brasil concentra disputa automobilística global. Com a inauguração da fábrica da Peugeot e o início da produção da Nissan, País será o primeiro a reunir fábricas completas das dez maiores montadoras do mundo. Jornal Gazeta Mercantil, São Paulo, p. c-01, sexta-feira, 04 e fim de semana, 05 e 06 de agosto.

WILLIAMSON, O. (1985). Economic institutions of capitalism. New York, Free Press.

WOMACK, J. P; JONES, D. T; ROSS, D. (1992). A máquina que mudou o mundo. $5^{\mathrm{a}}$ ed. Rio de Janeiro, Editora Campus.

ZILBOVICIUS, M. (1997). Modelos de produção e produção de modelos. in ARBIX, G. \& ZILBOVICIUS, M. (org.) De JK a FHC: a reinvenção dos carros. São Paulo, Editora Scritta.

ZILBOVICIUS, M. (1999). Modelos de produção, produção de modelos. Gênese, lógica e difusão do modelo japonês de organização da produção. São Paulo, FAPESP/Editora Annablume. 